\title{
Raising and matching in Pharasiot Greek relative clauses: a diachronic reconstruction ${ }^{1}$
}

This article studies the structure and origin of prenominal and postnominal restrictive relative clauses in Pharasiot Greek. Though both patterns are finite and introduced by the invariant complementizer $t u$, they differ in two important respects. First, corpus data reveal that prenominal relatives are older than their postnominal counterparts. Second, in the present-day language only prenominal relatives involve a matching derivation, whereas postnominal ones behave like Head-raising structures. Turning to diachrony, we suggest that prenominal relatives came into being through morphological fusion of a determiner $t$ - with an invariant complementizer $u$. This process entailed a reduction of functional structure in the left periphery of the relative clause, to the effect that the landing site for a raising Head was suppressed, leaving a matching derivation as the only option. Postnominal relatives are analyzed as borrowed from Standard Modern Greek. Our analysis corroborates the idea that both raising and matching derivations for relatives must be acknowledged, sometimes even within a single language.

Keywords: relative clause, prenominal, postnominal, raising, matching, Pharasiot Greek

\section{INTRODUCTION}

\subsection{Pharasiot Greek and its speakers}

This paper elucidates the structure and origin of two types of restrictive Headed Relative Clause constructions (hereafter HRCs) which co-exist today in Pharasiot Greek (PhG). PhG is a member of the inner Asia Minor Greek dialect group (iAMG), together with the varieties of Silli, Cappadocia and Pontus (Dawkins 1916: 205-206, 1940: 23, Triandaphyllidis 1993[1938]: 273-295, Janse 1998a,

[1] Acknowledgments.

Glossing abbreviations follow the Leipzig Glossing Rules. Additional abbreviations are as follows: AOR: aorist, MID: middle voice, PRT: (modal) particle, RA: relative article, RP: relative pronoun. 
Karatsareas 2011: 40). ${ }^{2}$ At the beginning of the 20th century, PhG was spoken by about 2600 people in six villages around modern-day Kayseri in central Turkey (Sarantidis 1899: 121, Dawkins 1916: 32-35). Between 1923 and 1925, its speakers were relocated to Greece in the context of the population exchange between Greece and Turkey, enacted as a supplementary protocol to the Treaty of Lausanne. Today, PhG is a moribund variety spoken by around 25 people in a number of villages in northern Greece. As of 2020, all its speakers are second generation refugees, their ages ranging between 66 and 84 . We have identified 10 male and 12 female speakers who evaluate their speaking and listening abilities in the dialect as fully fluent, which is also reflected in the conversational data elicited from them, as well as in comprehension tests. None of the informants has proficient writing (or reading) skills in the dialect: $\mathrm{PhG}$ has no standardized orthography and many speakers only received primary school education in (standard) Modern Greek. All PhG speakers are bilingual in PhG and Modern Greek. To the latter they were exposed from an early age onwards, but crucially not since their infancy: for all our speakers, the language to which they were first exposed at home was PhG. Today, PhG is their weaker language, as is generally the case with heritage languages. No speaker uses PhG on a daily basis; however, especially in the Greek village of Vathylakkos, we have noted that when two or more speakers come together, they often converse in PhG. Among the third-generation refugees there are a few who claim to have good passive knowledge of the dialect; however, they perform rather poorly on both comprehension and production tests.

Given the heritage nature of the dialect it is reasonable - as one reviewer surmised - to expect a multitude of structural differences between present-day

[2] Certain historical-linguistic criteria, for which see Karatsareas (2011: 40) and Manolessou (2019: 20-21), set iAMG dialects apart from other AMG varieties. The dialect of Mariupol, on the northern shore of the Sea of Azov, which is closely related to Pontic (Symeonidis \& Tompaidis 1999: 133-139), is also sometimes included in the iAMG group (e.g. Karatsareas 2011; but see Kisilier 2009: 18-20 for counterarguments). Setting aside the latter, all the remaining speakers of the AMG dialects, except for a small number of speakers of a Pontic sub-variety (Sitaridou 2013), were relocated in Greece after 1923. For the precise locations of where the dialects were spoken in Asia Minor, see Manolessou (2019: 22). 
PhG and its 'baseline', i.e. the standard against which we compare today's PhG speakers' linguistic knowledge (Montrul 2016: 168, Polinsky 2018: 10), which we take to be $\mathrm{PhG}$ as documented in the surviving written records from before and shortly after the population exchange (on which, see Section 2). There is indeed a limited number of discrepancies between heritage $\mathrm{PhG}$ and the baseline, pertaining to e.g. the shape of the genitive plural definite article, and the use of certain discourse particles and future markers (Bağrıaçı 2018: 63, 9596, $105 \mathrm{fn}$. 71). Such rapid restructuring in the speech of a final generation of speakers has been claimed to be typical of moribund languages (Bowern 2008: 139). These differences notwithstanding, we take our informants to be acrolectal speakers, '[...] who produce and understand the language in the manner that makes them closest to the baseline' (Polinsky 2018: 6).

Unless otherwise mentioned, the data from present-day PhG used in this article are drawn from a spoken corpus recorded between 2013 and 2017 (with data from 11 speakers), supplemented with judgements from 17 PhG speakers interviewed during multiple fieldwork trips between 2013 and 2017. Data were elicited primarily through standard acceptability judgment tasks. To avoid the so-called yes-bias (Polinsky 2018: 96), i.e. an informant's reluctance to reject ungrammatical material, we administered multiple stimuli of the same condition at least four times to the available speakers (over a period of four years), and we supplemented our data with translation tasks (into and from Modern Greek).

With this background in mind, we can now turn to the empirical domain of our research.

\subsection{Pre-and postnominal tu-relatives in $P h G$}

$\mathrm{PhG}$ restrictive relative clauses (henceforth $\mathrm{RCs}$ ) are finite and introduced by the morpheme $t u$. In the present-day language, prenominal (1a) and postnominal (1b) RCs co-exist, without there being any obvious semantic or pragmatic difference between the two structures: 
(1) (a) tu iðami si stráta

TU see.PST.1PL on.DET.F.ACC.SG road.F.ACC.SG

o nomát

DET.M.NOM.SG man.M.NOM.SG

(b) o nomát tu íðami

DET.M.NOM.SG man.M.NOM.SG TU see.PST.1PL

si stráta

on.DET.F.ACC.SG road.F.ACC.SG

'the man we saw on the street'

Adopting standard generative terminology, we will refer to the nominal category modified by the RC as the 'Head' of the RC (highlighted in boldface throughout the examples). As will be discussed in Section 2, whereas the pattern in (1a) is attested throughout the documented history of the language, postnominal RCs (1b) only became productive after the 1930s.

Prenominal RCs are at least optionally available in all iAMG varieties (Dawkins 1916: 200-201, Anastasiadis 1976: 173 a.o.). It is standardly assumed that this structure came about through long-term contact with Turkish (Dawkins 1916: 201-202, Andriotis 1948: 48, Janse 1998b, 1999, Thomason 2001: 74), a language which exclusively has prenominal RCs. ${ }^{3}$ Here we do not wish to take issue with the important role language contact played in causing this pattern to thrive; neither will we make any claims about the historical sources of prenominal $\mathrm{RCs}$ in iAMG varieties other than PhG. However, for the particular case of $\mathrm{PhG}$, a pure language-external account of the origins of prenominal RCs does not explain the origin of the complementizer $t u$, which has no corresponding form in any other Modern Greek dialect (and which was not borrowed from Turkish). Furthermore, proponents of the idea that prenominal RCs originated through language contact assume that what changed is only linear constituent order: the innovative prenominal RCs are thought to be derived from their pre-existing postnominal counterparts, as a reflex of a more general development in which

[3] A second, marked, pattern for HRC formation in Turkish involves finite postnominal RCs introduced by the morpheme $\mathrm{ki}$. This pattern has fallen into disuse today (Kornfilt 1997: 60). Some analyses treat $k i$-relatives as paratactic clauses (e.g. Schroeder 2002). 
word order in iAMG was aligned with the typical 'head-final' syntax of Turkish. However, although this scenario is not a priori implausible, it would remain to be determined precisely under which conditions this instance of syntactic borrowing took place. In addition, the idea of word order copying does not explain a number of structural properties of prenominal $\mathrm{RCs}$ in $\mathrm{PhG}$, to which we turn now.

\subsection{Raising and matching}

One important observation concerning the two patterns in (1) is that they consistently behave differently with respect to a number of syntactic tests which are standardly used to distinguish 'matching' from 'raising' RCs. Two simplified structures for matching and raising RCs are given in (2) (cf. Cinque 2015: 2, his (1)-(2)). ${ }^{4}$ For the sake of simplicity, we are at this point abstracting away from the linear ordering of the RC and the Head:

(2) (a) MATCHING

the book [ which $/$ that/Ø I bought $t_{\mathrm{i}}$ ]

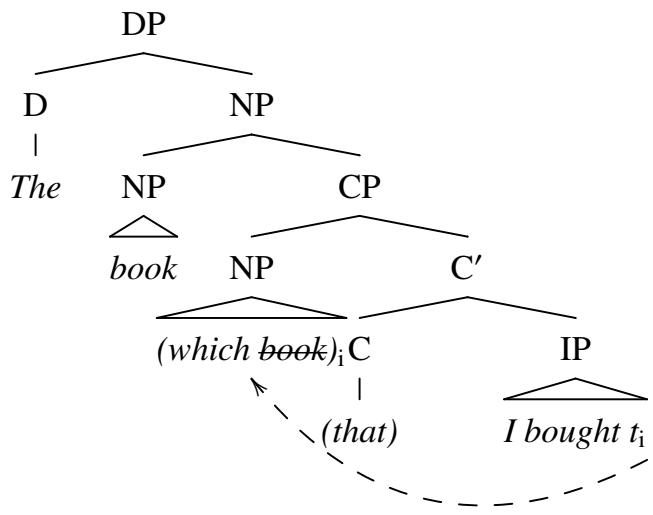

(b) RAISING

the book $\mathrm{k}\left[\left[\text { which } t_{\mathrm{k}}\right]_{\mathrm{i}} /\right.$ that $/ \varnothing \mathrm{I}$ bought $\left.t_{\mathrm{i}}\right]$

[4] Many different variants exist of both analyses: for an overview see de Vries (2002: chapter 3 and App. 3). For our purposes nothing hinges on the differences between these analyses. 


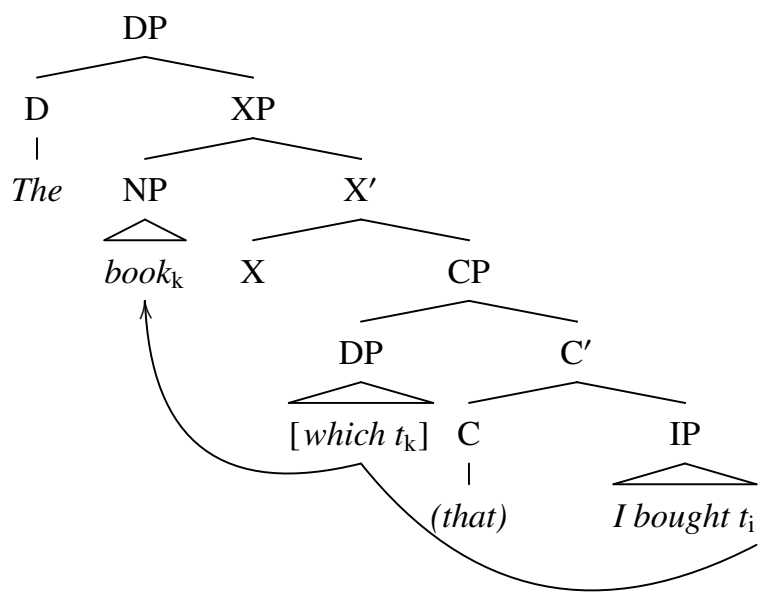

In a matching derivation (2a), the Head that is interpreted is an NP base-generated outside the relative CP. Inside the RC there is a 'matching' internal Head, which optionally raises (as indicated by the dotted arrow), and which is always deleted under identity with the external Head (for various implementations, see Lees 1961, Chomsky 1965, Sauerland 1998). In contrast, in raising derivations (2b) the internal Head is interpreted, but only so after it raises from within the RC to a position contiguous to the external determiner (for early discussion see Brame 1968, Schachter 1973, Vergnaud 1974; for recent analyses see a.o. Kayne 1994, Bianchi 1999, Bhatt 2002, de Vries 2002).

In a series of recent publications, Guglielmo Cinque has proposed a unified analysis of all relativization structures available in Universal Grammar (Cinque 2003, 2008a, 2015, 2016, 2020). This analysis is rooted in the author's earlier work aimed at providing a syntactic account of a fundamental, and crosslinguistically robust, asymmetry concerning the relative order of nouns and their modifiers (demonstratives, numerals, adjectives): simply put, to the left of a noun, the order of modifiers is unique, while to the right more possibilities exist (Greenberg's Universal 20). Adopting Kayne's (1994) antisymmetric framework, which bans all symmetrical mergers of modifiers, to the left as well as to the right of an XP, Cinque suggests that adnominal modifiers are always externallymerged above NP, resulting in a 'modifier - N' base order. Postnominal modifiers 
are derived by NP-movement to the specifier of agreement projections, whereby NP can optionally pied-pipe some functional superstructure (Cinque 1996, 2005, 2009). Extending this analysis to all RC types observed in natural languages, and taking into account the respective order of RCs and other adnominal modifiers, Cinque concludes that all types of RCs can be analyzed as phrasal modifiers, universally first-merged in the extended projection of a noun.

The basic structure for finite, restrictive RCs from which various surface patterns can be derived is given in (3) (from Cinque 2008a: 10, his (16)). ${ }^{5}$ For illustrative purposes, English words were added to this structure, forming the HRC the two nice books that John bought. According to Cinque, all RCs (including FRCs, see below) are double-Headed: they have both an internal and an external (nominal) Head, the whole structure being projected by the external Head noun, cf. (3). The top node of both the internal and the external Head is taken to be a 'little dP', i.e. an extended NP which is not endowed with full functional superstructure. As we will see in Section 3.2, in PhG the d-node is spelled out overtly. Parametric variation (raising vs. matching; prenominal vs. postnominal; externally- vs. internally-Headed) is taken to be a function of (i) whether or not the internal and/or external Head move to the specifier of one of the C-projections in between FP (the functional head hosting the RC proper) and the external determiner (D), and (ii) which of the two Heads undergoes phonological deletion. Consider how exactly this works.

[5] Cinque $(2015,2016,2020)$ proposes a slightly different structure, in which the C-projections hosting relative complementizers and (optionally) the internal and/or external Head are not directly selected by D, but rather merged on top of the relative IP in SpecFP. See further (Cinque 2020: §3.5) for different merge positions of finite non-infinitival, participial and non-restrictive RCs. 


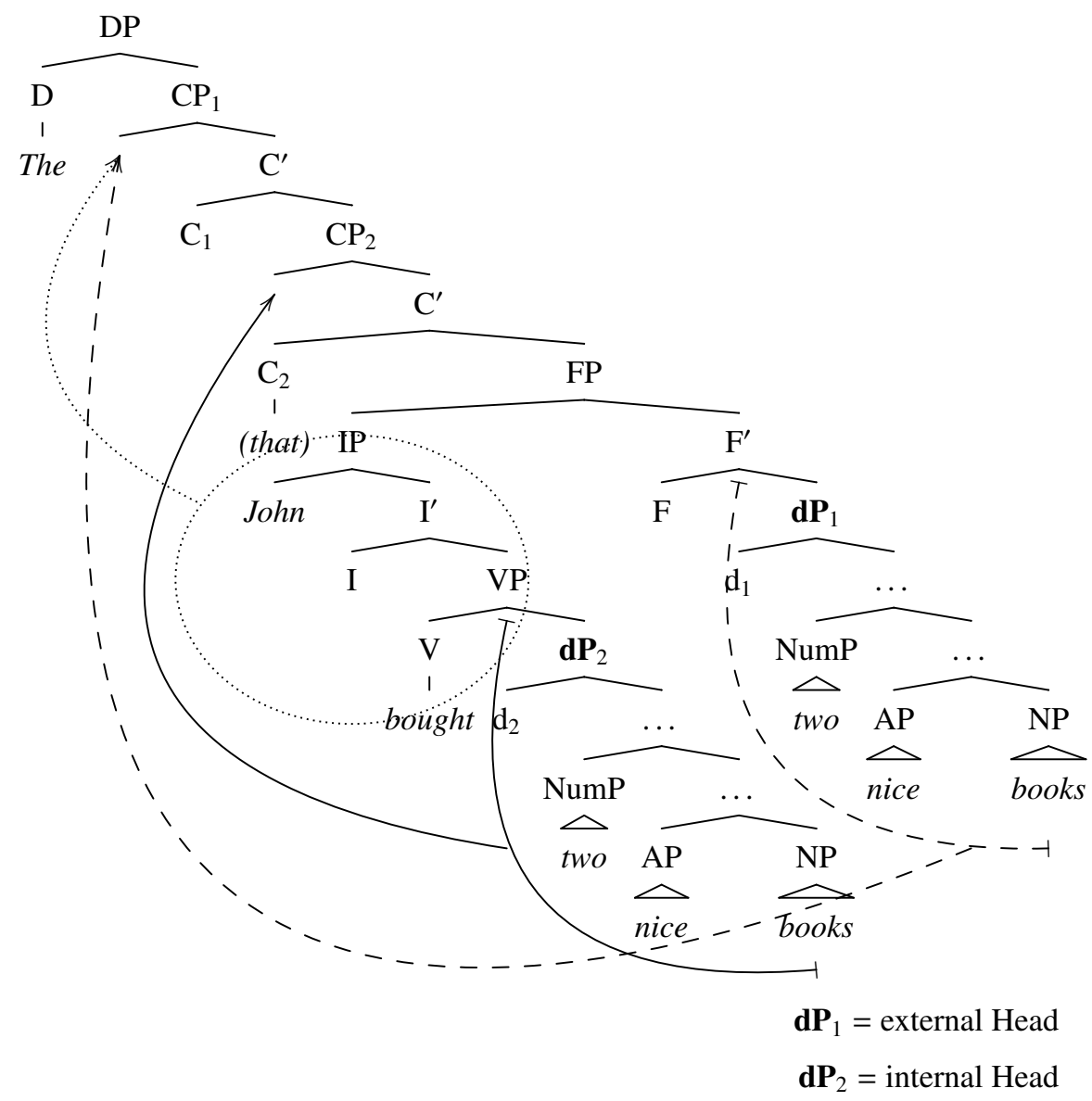

In the case of postnominal RCs, a raising derivation obtains when only the internal Head moves to $\mathrm{SpecCP}_{2}$ (cf. the solid arrow in (3)), causing phonological deletion of the external Head under c-command. If, on the other hand, raising of the internal Head is followed by movement of the external Head to SpecCP (cf. the dashed arrow in (3)), it is the latter that deletes the former and ends up being pronounced, yielding a postnominal RC of the matching type. In prenominal $\mathrm{RCs}$, a raising derivation is identical to what we have in the postnominal case (movement of the internal Head to $\mathrm{CP}_{2}$ and deletion under c-command), modulo the additional movement step of the remnant IP (circled) to $\mathrm{CP}_{1}$. In prenominal matching RCs nothing moves at all, and the external Head is spelled out overtly, 
eliding the internal Head 'backward' in a type of ellipsis which is reminiscent of VP deletion, which can apply both forward and backward, without any ccommand requirement by the antecedent (John might $<$ do this job $>$ but I won't $<$ do this job>). ${ }^{6}$ The derivation of internally-headed RCs is the converse of the matching derivation of prenominal RCs: the internal head controls the 'forward' deletion of the external head. ${ }^{7}$ Finally, the syntax of FRCs - both definite and universal ones - is essentially the same as that of HRCs: the former feature two silent Heads (with which wh-pronouns are associated if they exist in a given language), namely a phonologically null classifier-like element such as PERSON, AMOUNT, MANNER Or THING.

In this paper, we adopt Cinque's double-Headed analysis of all types of RCs, which also neatly incorporates the, by now standard, idea that HRCs involve a CP that is dominated by an external determiner (D) (cf. Partee 1975 and much subsequent work).

\subsection{Summary and roadmap}

As we will discuss at length in Section 3, one crucial observation is that postnominal but not prenominal $\mathrm{RCs}$ in $\mathrm{PhG}$ display reconstruction effects and island sensitivity, suggesting that the former but not the latter involve syntactic movement, namely Head-raising. We suggest that the etymology of the relativizer $t u$ is crucial to understand how prenominal matching RCs came about in the language. Specifically, we analyze $t u$ as originally bimorphemic, consisting of a definite determiner $t$ - (of category D) and an invariant (relative) complementizer $u$ 'that' (i.e. a C-element). The morphological fusion of these elements around the 3rd c. CE, we claim, eliminated SpecCP (or any other position between D and C) as a possible landing site for a Head NP. Interpreting this in the light of

[6] Cinque (2020: $§ 2.1 .1)$ points out that there might indeed be a difference between VP deletion and $\mathrm{dP}$ deletion, only the latter of which seems to be obligatory cross-linguistically, excluding those which allow double-Headed RCs, although a representative linguistic survey of VP ellipsis is missing.

[7] This is only one possible derivation of internally-Headed RCs, which do not form a homogeneous class (Hiraiwa 2017: 7, Cinque 2020: $§ 2.3 .3-2.3 .7$.) 
the unified approach to RCs initiated in Cinque (2003), we propose that overtly spelling out the external Head turned out to be the prevalent option to form HRCs with $t u$ (the only alternative being internally-Headed RCs, which as we will see only constitute a minority pattern). Our account thus captures not only the lack of reconstruction effects and island sensitivity in prenominal RCs, but it also explains the emergence of $t u$, which does not have an analogue in other Modern Greek dialects. In all likelihood, the eventual success of prenominal RCs is to be ascribed to Turkish influence, given that Greek and Turkish co-existed for about ten centuries in Asia Minor, and given that there is ample independent evidence for massive linguistic borrowing from Turkish in various areas of the $\mathrm{PhG}$ grammar. As to postnominal RCs, which, judging by their absence in the earliest written records, are a recent innovation, we claim that they emerged due to contact with Modern Greek, to which speakers of $\mathrm{PhG}$ have been exposed since, at least, their relocation to Greece in 1923-1925. We suggest that the $\mathrm{PhG}$ relativizer $t u$ was identified with the Modern Greek invariant complementizer $p u$ 'that', and that the structure of postnominal RCs of Modern Greek was copied into $\mathrm{PhG}$ following this identification. As we will argue, two facts support this claim: first, both Modern Greek and PhG postnominal RCs bear characteristics of Head-raising structures, and second, neither Modern Greek nor PhG allow for constituent fronting inside postnominal RCs.

In sum, our paper sheds light on the synchrony and diachrony of both types of HRCs in PhG, and more generally on the development of relativization strategies in the Hellenic language family. At a theoretical level, it provides evidence for the claim that both raising and matching structures should be assumed for RCs, even within a single language (Sauerland 1998, 2000, Bhatt 2002, Hulsey \& Sauerland 2006, Sichel 2014, Deal 2016).

The article is structured as follows. In Section 2 we introduce the basic facts about PhG HRCs, before and after the population exchange, up to today. In Section 3, we apply four tests to differentiate matching and raising to present-day PhG RCs, and conclude that prenominal RCs involve matching, and postnominal 
ones raising. We proceed to show how prenominal and postnominal RCs in PhG can be analyzed in Cinque's unified framework. Turning to the diachronic analysis, in Section 4 we first provide an overview of relativization strategies in the history of Greek, focusing in particular on the typology of relativizers and on the linear order of the RC with respect to the Head. In Section 5, we propose that the key to understanding the syntactic behavior of prenominal $\mathrm{RCs}$ in $\mathrm{PhG}$ resides in the etymology of the relativizer $t u$. In Section 6, we argue that postnominal RCs in PhG were borrowed from Modern Greek. Section 7 concludes.

\section{Relativization in the attested history of PhG}

The attested history of $\mathrm{PhG}$ stretches back to the late 19th century, and today a substantial body of texts is preserved, which allows us to have a good idea about the state of the language before it came into intensive contact with Modern Greek (see Bağrıaçık 2018: 14-17 for a list of these texts). In this section we provide a descriptive overview of relativization strategies in the attested history of $\mathrm{PhG}$, with special attention on constituent order (prenominal vs. postnominal RCs). For reasons to be elaborated on in section 2.1 , it is important to make a distinction between restrictive and non-restrictive relatives: in a nutshell, on the assumption that the latter are amenable to an analysis in which the RC is in fact an appositive free relative clause (FRC), which may follow or precede a nominal associate (de Vries 2002: clapter 6, §5.3), we will show that initially only the prenominal RC-pattern could unambiguously express restrictive modification in $\mathrm{PhG}$. In later stages, on the other hand, a restrictive interpretation becomes available with postnominal RCs too.

\subsection{0s-1923: the predominance of prenominal RCs}

Dawkins (1916: 201) was the first author to claim that RCs in PhG are prenominal. A systematic survey of surviving PhG texts from before the population exchange of 1923 by and large confirms this, as the overwhelming majority of the attested RCs are indeed prenominal (73 out of 81 tokens, i.e. $90.12 \%$ ). In all cases, the 
morpheme $t u$ occurs at the left edge of the RC. Two examples are given in (4), featuring a definite (4a) and an indefinite Head (4b) respectively. The Head can also be animate or inanimate, and it can have any number, gender and case specification (which we cannot illustrate here due to reasons of space). ${ }^{8}$

(4) (a) Čo istámi $\mathrm{s}[[\langle\mathrm{t}\rangle \mathrm{u}$ čo ši yéna $]$ not stay.1SG at.TU not have.3SG beard.N.NOM.PL

to nomáti]. ${ }^{9}$

DET.M.ACC.SG man.M.ACC.SG

'I do not stay with the man who does not have beard.'

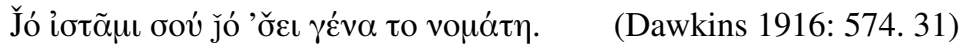

(b) $[\ldots] \mathrm{s}$ értune [tu kóftune čufále] ðío]].

PRT come.3PL TU cut.3PL head.N.NOM.PL two 'Let (any) two (men) who cut heads come.'

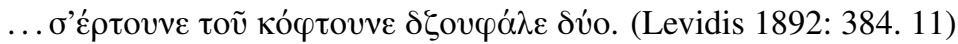

The nominal Head in these examples occur in the absolute final position of the complex noun phrase and it always bears the case assigned to it by an element in the matrix clause (as does any determiner accompanying it), even when there is a potential mismatch between the case requirements inside and outside the RC. This suggests that the Head is external to the RC, as indicated by the bracketing.

Prenominal RCs are most often restrictive: of 73 prenominal RCs, 66 are unambiguously restrictive (8) and four are unambiguously non-restrictive (5).

(5) č [ačínos [tu díge sa xére], and DEM TU give.IPFV.PST.3SG to.DET.N.PL.ACC hand.N.PL.ACC

o Júđas], káčefke [...]

DET.M.NOM.SG Judas.M.NOM.SG speak.PFV.PST.3SG

'.... and that Judas, who betrayed, was speaking...'

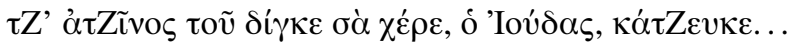

[8] Greek examples are given as they appear in the original source, and followed by a transcription which remains as close as possible to the phonetic facts of the era as described in Horrocks (2010[1997]). English translations are ours, unless they are available in the original source. Data from papyri were retrieved from papyri.info. Other textual sources are listed at the end of this paper.

[9] When the preposition $s$ 'in/on/at' precedes the morpheme $t u$ (or a definite article with intial [t]), the initial [t] of latter is very often omitted (following [t] $>[\mathrm{s}]$ assimilation) (Dawkins 1916: 598, Anastasiadis 1976: 172, II). In (4a) (and in similar contexts), we reconstruct the omitted [t] inside angle brackets. 
(de Lagarde 1886: 8. 16)

Not discussed in Dawkins (1916) is a type of restrictive HRC in which the Head does not sit at the right edge of the complex DP, but rather within the RC (6):

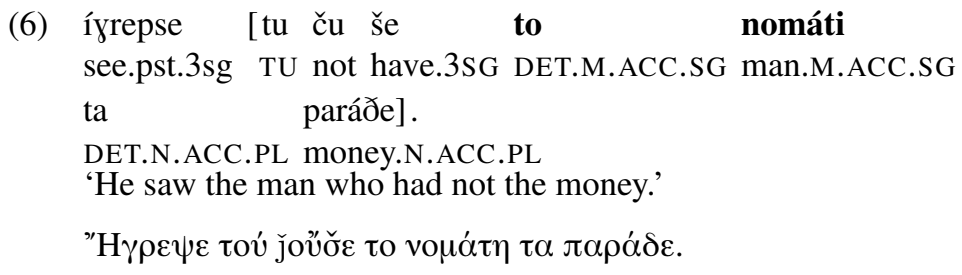

(Dawkins 1916: 530. 24-25)

Examples like (6) could be analyzed as Head-internal RCs not containing any RC-internal 'gap' (Cole 1987, Basilico 1996). At least from a quantitative point of view, this pattern is rather marginal: in texts from before 1923, we found only three HRCs (out of 81, i.e. 3.7\%) in which the Head is followed by some material that unambiguously belongs to the RC. Remarkably, although the Head occurs within the RC, its case is assigned externally, via some mechanism whose nature is not at this point clear to us.

Among the remaining five non-prenominal RCs (6.17\% of all instances), we recognize two patterns: one which features a full nominal Head (three tokens, in two of which the Head is further modified by a demonstrative (7a)), and one in which the Head is apparently a bare demonstrative (two occurrences, (7b)). Crucially, all these tokens, which at first sight qualify as postnominal HRCs, are in fact interpretively non-restrictive. ${ }^{10}$

[10] The one example cited in Dawkins (1916) in which the Head is not modified by a demonstrative, is also non-restrictive. Consider (i) with the piece of discourse immediately preceding it:

(i) That king $[\ldots]$ wrote a letter saying: "I'm sending a youth to come from here." [...] And the boy $[. .$.$] mounted the king's horse, goes off.$

Píren če [to $\quad$ xartío, $\quad$ tu éfrapse o
take.PST.3SG also DET.N.ACC.SG letter.N.ACC.SG TU write.PST.3SG DET.M.NOM.SG
vasilós]].
king.M.NOM.SG
'He took also the letter, which the king had written.'



(7) (a) [...] [ačíno tiz líres, [tu
DEM DET.F.ACC.PL gold piece.F.ACC.PL [TU
sórepsane [...] san dái]].
collect.PST.3PL in.INDF bag.N.NOM.SG
'... the gold which they had collected [... ] in a bag'

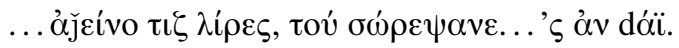

(Dawkins 1916: 546. 26-27)
(b) $[\ldots]$ píye se $\mathrm{t}$ áyu, [ačínos $[\mathrm{tu}$
go.PST.3SG to DET.N.ACC.SG other.ACC.SG DEM TU
éši $\mathrm{t}$ aóni]].

have.3SG DET.N.ACC.SG threshing.floor.N.ACC.SG

'... (the old man) went to the next, he who had the threshing floor.'

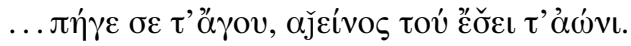

(Dawkins 1916: 524. 17)

Before analyzing the patterns in (7), we should mention that the morpheme $t u$ is also employed in argumental FRCs (who(ever), what(ever), which(ever)), which on the surface differ from HRCs only in that they do not feature an overt nominal Head. ${ }^{11}$ As indicated in the translation of (8), these FRCs are often ambiguous between a universal/free choice and a definite reading (on which, see Dayal 1997, von Fintel 2000, Caponigro 2003 - see also footnote 21).

(8) Záir [tu tavrí maxéri] a ipá mo to surely TU pull.3SG knife.N.NOM.SG PRT go.3SG with DET.N.ACC.SG maxéri.

knife.N.ACC.SG

'Surely, the one who/whoever pulls a knife will perish by a knife'

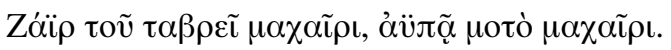

(de Lagarde 1886: 10. 1)

A FRC with $t u$ can feature a verb with either singular (8) or plural agreement

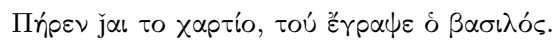

(Dawkins 1916: 498. 1-2)

Dawkins also seems to have had in mind a non-restrictive reading, witness the comma he inserts between the Head and the relativizer, both in the example and in the translation.

[11] $T u$ is used in three more contexts: complement clauses to a number of - mainly factive predicates, complement clauses to prepositions (yielding adverbial clauses) and finite sentential subjects (see Bağrıaçık 2018: 125-126, 129-130). The same uses are still preserved in presentday PhG. We will not further be concerned with these constructions. 
(9), and when functioning as a subject, the FRC itself triggers either singular

(8) or plural (9) agreement on the matrix verb, depending on the number of the understood referent:

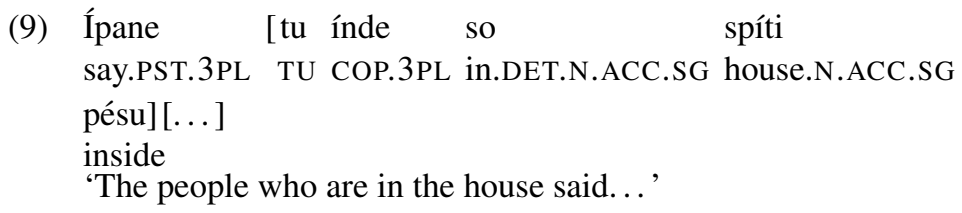

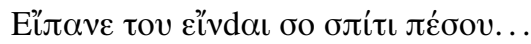

(Dawkins 1916: 544. 16-17)

We will assume that (8)-(9) are RCs with a silent nominal Head, which triggers agreement on the RC-internal predicate and, in the case of subject FRCs, also on the matrix verb. For expository reasons, however, we will continue to refer to HRCs with a silent Head as FRCs.

Returning to the cases in (7), we propose that both examples involve a FRC, i.e. a HRC with a null Head. Given that in such examples the complex NP containing the $t u$-relative always refers to an established discourse referent, we take this analysis to be interpretively plausible. The type illustrated in (7a) may involve a definite FRC in apposition to a nominal modified by a demonstrative pronoun: (7a) can thus literally be rendered as those gold pieces, (the ones) which they collected in a bag, in a structure where the RC non-intersectively modifies a DP whose referent is discourse-given (see de Vries 2002: 218-223, 2006 for an analysis according to which postnominal non-restrictive RCs are FRCs in apposition to an 'antecedent'). ${ }^{12}$ As for the second sub-type (7b), despite their overall abundance, prenominal RCs are never attested with a bare demonstrative Head (neither before nor after the population exchange). From this, we conclude that demonstrative pronouns obligatorily preceded RCs - a word-order restriction that still holds in present-day $\mathrm{PhG}$ (Bağrıaçık 2018: 75). A natural analysis of the

[12] Example (i) in footnote 10 can also be analyzed as a FRC in apposition to a definite nominal (he also took the letter, (the one) which the king had written). Similarly, prenominal non-restrictive RCs as in (5) can be analyzed as definite FRCs followed by an appositive DP (de Vries 2006: 264-265) ((that one) who betrayed him, Judas). This would be consistent with the claim that true prenominal non-restrictives do not exist in the languages of the world (de Vries 2006: 264, 266, Citko 2008; but see also Cinque 2008b: 122 fn. 35). 
pattern in (7b) then involves a definite FRC, whose null Head is further modified by a demonstrative pronoun. The fact that the demonstrative pronoun may carry any number and gender specification suggests that it does indeed agree with a nominal element, albeit a phonologically covert one. Cases as (7b) would thus be 'Headed relatives in disguise', rather than 'light-headed relatives' (both in the sense of Citko 2004).

To conclude, there is no unambiguous evidence that before $1923, \mathrm{PhG}$ had postnominal HRCs; rather, the vast majority of HRCs are prenominal, with Headinternal RCs constituting a minority pattern. If real, the existence of the latter in earlier stages of $\mathrm{PhG}$ should not come as a surprise, as this pattern is not uncommon in languages which also have prenominal RCs (Cole 1987). Assuming that non-restrictive relatives are FRCs in apposition, along the lines described above, in what follows we will only be concerned with restrictive HRCs.

\subsection{2-today: the gradual rise of postnominal RCs}

HRCs in the texts produced after the population exchange are also finite and introduced by the complementizer $t u$. Concerning the first decades after the exchange, Andriotis (1948: 48) and Favis (1948: 185) claim that RCs in PhG are always prenominal. This is by and large confirmed by corpus data from texts dating from ca. 1930-1970, but crucially, in this period we also find a fair amount of postnominal RCs which are unambiguously restrictive. The existence of postnominal restrictive RCs was first explicitly commented upon by Anastasiadis (1976: $174 \gamma^{\prime}$ ): '[o]ccasionally, the [RC head] is placed at the beginning of the RC for emphasis' (our translation). As the author does not elaborate on what exactly he means by "emphasis" it is difficult to interpret this statement, and this is compounded by the fact that he only gives one example of a postnominal $\mathrm{RC}$ (which is moreover quoted out of context), reproduced here in (10). 
(10) [A nomát [tu čo tro to

INDF man.M.NOM.SG TU not eat.3SG DET.N.ACC.SG

málin tu]], a vre日í kanís n

wealth.N.ACC.SG he.GEN PRT find.PASS.3SG someone.NOM PRT

da fa.

3OBJ eat.3SG

'A man who does not spend his wealth, there will be someone to spend it.'

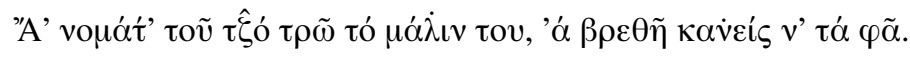

Anastasiadis (1976: $\left.174 \gamma^{\prime}\right)$

In any event, Anastasiadis (1976) clearly acknowledges the existence of postnominal restrictive HRCs, which is confirmed by a survey of (oral and written) corpus data from after the population exchange.

In the earliest text from after the population exchange, namely the collection of proverbs by Loukopoulos \& Loukatos (1951), we see that out of 43 unambiguously restrictive HRCs, 27 are prenominal, 14 are postnominal (cf. (11), and two are internally-Headed (12). Importantly, ten of the postnominal tokens can be dated around 1946-1948. The two internally-Headed tokens date from before 1940.

(11) $\quad$ To

fíði, [tu čo ftáni se ména]] na

DET.N.NOM.SG snake.N.NOM.SG TU not molest.3SG to I.ACC PRT jasatiési šile xrónes.

live.3SG thousand years

'May the snake that does not molest me live a thousand years.'

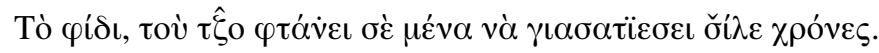

(Loukopoulos \& Loukatos 1951: 46. §241)

(12) [Tu irízi to krasí ksíði]

TU turn.3SG DET.N.NOM.SG wine.N.NOMSG vinegar.N.NOM/ACC.SG ínete vinató.

become.3SG strong.SG

'The wine that turns into vinegar becomes strong.'

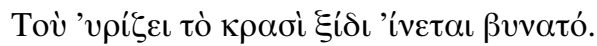

(Loukopoulos \& Loukatos 1951: 44. §232)

In texts from between $c a$. 1950-1970, we found no cases of internally-Headed RCs. The majority of instances of unambiguously restrictive RCs are prenominal 
(47/52), but restrictive postnominal RCs such as (13) are also attested (viz. five times):

[...] aesmó

$\mathrm{s}[$ to

potámin

[tu

holy.water.N.NOM.SG from.DET.N.ACC.SG creek.N.ACC.SG TU

vkéni stin eklesían popukátu]].

spring.3SG from.F.ACC.SG church.F.ACC.SG below

'... holy water from the creek that springs from beneath the church.'

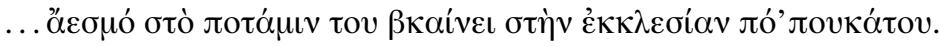

(Theodoridis 1950s: 55. 1-2)

Next, in a number of stories recently recorded by Papadopoulos (2011), we find both postnominal and prenominal restrictive RCs, but no internally-Headed RCs. Our synchronic data also confirms that modern-day PhG has both prenominal and postnominal restrictive HRCs. In the spoken corpus of 11 hours collected between 2013 and 2017 (on which, see Bağrıaçık 2018: 12-13), both types of restrictive HRC with a nominal Head seem to be freely available. We found no internallyHeaded RCs, and this pattern is also uniformly rejected by our informants.

All the corpus findings reported on the last two sections are summarized in Table 1:

\begin{tabular}{l|rr|rr|rr|r}
\hline & Prenominal & \multicolumn{2}{|c|}{ Postnominal } & Head-int & Total \\
\cline { 2 - 9 } & $\#$ & $\%$ & $\#$ & $\%$ & $\#$ & $\%$ & $\#$ \\
\hline $1886-1923$ & 66 & 95.7 & 0 & 0 & 3 & 4.3 & 69 \\
\hline \multicolumn{7}{c}{ population exchange } \\
\hline $1932-1940$ & 26 & 81.25 & 4 & 12.5 & 2 & 6.5 & 32 \\
\hline $1946-1948$ & 1 & 9.1 & 10 & 90.9 & 0 & 0 & 11 \\
\hline $1950-1970$ & 47 & 90.38 & 5 & 9.62 & 0 & 0 & 52 \\
\hline 2011 & 3 & 37.5 & 5 & 62.5 & 0 & 0 & 8 \\
\hline $2013-2017$ & 13 & 40.63 & 19 & 59.38 & 0 & 0 & 32 \\
\hline
\end{tabular}

Table 1

Restrictive RCs in the attested history of PhG (up to 2017).

As to the syntax of HRCs in present-day $\mathrm{PhG}$, native speaker judgments and data from the oral corpus reveal that there is no restriction on the nature of 
the Head, which can be definite or indefinite, and have any gender and number specification. In addition, the Head bears the case assigned to it by a matrix case assigner: for example, in (14) and (15) the Head receives nominative case, due to the fact that the whole complex NP functions as the subject of the matrix clause. When marked for accusative case (i.e. the case it would be assigned RCinternally), the structures become ungrammatical:

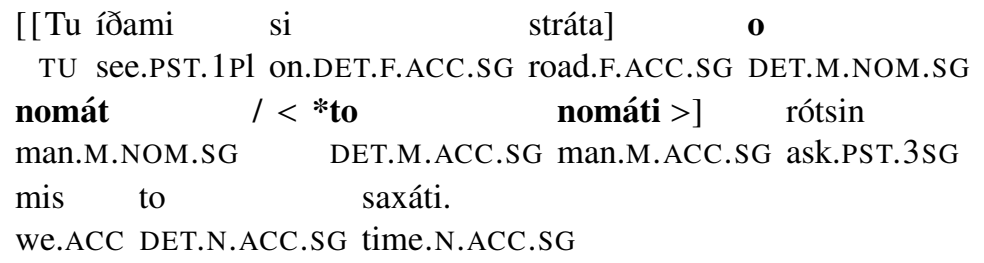

(15) $[\mathbf{O}$ nomát $\quad /<*$ to

nomáti >

DET.M.NOM.SG man.M.NOM.SG

DET.M.ACC.SG man.M.ACC.SG

[tu íđami si stráta]] rótsin

TU see.PST.1PL on.DET.F.ACC.SG road.F.ACC.SG ask.PST.3SG

mis to saxáti.

we.ACC DET.N.ACC.SG time.N.ACC.SG

'The man we saw on the road asked us the time.'

We also could not detect any semantic or pragmatic difference between prenominal and postnominal RCs. Both are accepted and used, apparently indiscriminately, although speakers unanimously agree that prenominal RCs sound archaic. The two variants can be observed in the speech of the same speaker today, such as (16):

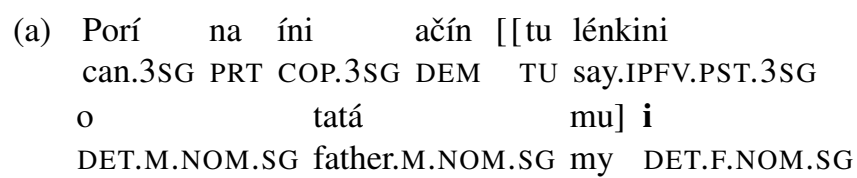

ikóna].

icon.F.NOM.SG

'It can be that icon that my dad used to talk (about).'

[K. (fem, 87 yrs.), 02.03.2019, 5:13-5.16]

(b) $[$ To xáxu [tu pérkini] $]$,

DET.N.NOM.SG share.N.NOM.SG TU take.IPFV.PST.3SG 
axšamdán kleftínkan da.

in.the.evening steal.IPFV.PST.3PL 3OBJ

'The share he used to receive, they would steal it in the evening.'

[K. (fem, 87 yrs.), 02.03.2019, 13:50-13.53]

To sum up, genuine postnominal HRCs appeared after the speakers were relocated to Greece, and their frequency has risen considerably over the last 50 years. Let us now turn to the syntax of both types of HRCs.

\section{THE SYNCHRONIC SYNTAX OF PRE- AND POSTNOMINAL RCS IN PHG}

Recall from Section 1.3 that the major difference between raising and matching RCs concerns the status of the Head: only in raising structures does the phonologically overt Head originate inside the relative CP. For this reason, in raising RCs we expect to find 'connectivity effects' indicative of an $\bar{A}$-dependency. In this section we will apply four tests discriminating between raising and matching RCs to the PhG data. Specifically, these tests involve phrasal idioms, quantifier scope, weak islands and amount relatives.

\subsection{RCs in PhG: raising or matching?}

\subsubsection{Idioms}

It is standardly assumed that the object of a verb + object $(\mathrm{V}+\mathrm{O})$ idiom chunk is not semantically autonomous, and that the non-literal meaning can only come about in a local configuration. Idioms have thus often been used to provide support for the raising analysis, the logic of the argument being that if the idiomatic reading of a $\mathrm{V}+\mathrm{O}$ chunk is preserved when the object is relativized, one would have to conclude that the relevant construction involves Head-raising (Schachter 1973: 31-32, attributed to Brame 1968). In (17), for instance, the fact that the idiomatic reading make headway can be obtained in the context of a HRC can naturally be accounted for by saying that the Head (headway) is interpreted 'under reconstruction' in its RC-internal base position as the complement of make.

(17) [The headway [(that) we made ]] was satisfactory. 
$\mathrm{PhG}$ possesses numerous $\mathrm{V}+\mathrm{O}$ idioms:
(a) Tro pušmáni.
eat.1SG regret.N.NOM.SG
'I (have) regret.'
(b) Éxu ftálmi. have.1SG eye.N.NOM.SG 'I have my eyes (on someone).'

Certain idioms, such as (18b), do not allow O-relativization at all, whereas others do, the important factor being the semantic opacity/degree of lexicalization of a given idiom. ${ }^{13}$ The idiom in (18a) does allow for O-relativization, with retention of the idiomatic reading. There is however one important restriction: this state of affairs only holds for postnominal RCs (19a); the same configuration in prenominal contexts results in unacceptability (19b).
(a) $[$ To
pušmáni
[tu éfain
]] $\mathrm{xa}$
DET.N.NOM.SG regret.N.NOM.SG TU eat.PST.3SG
PRT
ta skotósi.
3oBJ kill.3sG
'The regret that he had would kill him.'

(b)
* [ [ Tu éfain ] to
pušmáni]
$\mathrm{xa}$
TU eat.PST.3SG
DET.N.NOM.SG regret.N.NOM.SG PRT
ta skotósi.
3OBJ kill.3SG
(int.) 'The regret that he had would kill him.'

The fact that reconstruction of the Head is possible in postnominal but not in prenominal RCs suggests that only the former involve raising.

\subsubsection{Scope $Q>N u m$}

Further connectivity effects can be observed in RCs featuring two scope-taking expressions. Aoun \& Li (2003) show for English that a relativized object NP

[13] Bianchi (1993: 370) distinguishes two types of idioms in Italian based on whether Orelativization (and retention of the idiomatic reading) is available or not. de Vries (2002: 78) calls those $\mathrm{V}+\mathrm{O}$ sequences that allow relativization collocations. 
modified by a numeral can be interpreted within the scope of a universally quantified subject NP inside the RC (see also Bianchi 1999: 45-46):

(20) I phoned [the two patients [that every doctor will examine tomorrow]].

$(\forall>2 ; 2>\forall)$

(Aoun \& Li 2003: 98 their (7c))

In (20), the Head can take both narrow and wide scope with respect to the quantified subject inside the RC, namely every doctor. The wide scope reading $(2>\forall)$ goes with linear order. In the narrow scope reading $(\forall>2)$, relevant for the connectivity effects discussed here, the Head is interpreted in the c-command domain of the quantified subject every doctor, yielding a distributive reading with twice as many patients as doctors. The availability of this reading suggests that the Head must have raised from the RC-internal object position.

In $\mathrm{PhG}$, an indefinite direct object with a numeral modifier which is ccommanded by a universally quantified subject NP is always interpreted distributively (21).

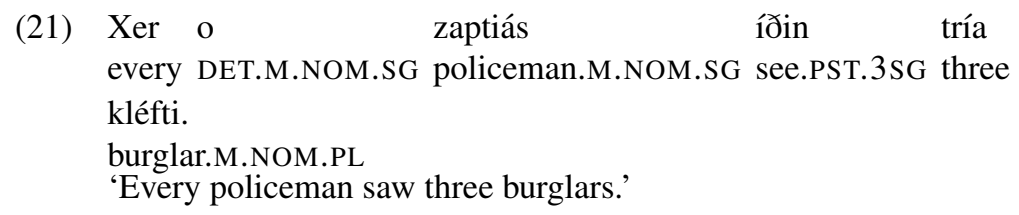

(3 burglars per policeman, i.e. $\forall>3 ; * 3>\forall$ )

Interestingly, the distributive reading of an indefinite object is preserved under relativization, but only in postnominal RCs (22a) vs. (22b). This holds true even if the Head ends up being combined with a definite external determiner; note that an additional non-distributive reading also becomes available in (22a).
(a) Piésam
[ta
tría tis
kléfti catch.PST.1PL AGR.PL three DET.M.ACC.PL burglar.M.ACC.PL [tu íđin xer o zaptiás TU see.PST.3SG every DET.M.NOM.SG policeman.M.NOM.SG ] ].

'We caught the three burglars that every policeman saw.' 
(b) Piésam [ [ tu ídin xer o

catch.PST.1PL TU see.PST.3SG every DET.M.NOM.SG

zaptiás _ ] ta tría tis

policeman.M.NOM.SG AGR.PL three DET.M.ACC.PL

kléfti].

burglar.M.ACC.PL

'We caught the three burglars that every policeman saw.'

(3 specific burglars)

The availability of the narrow scope reading in postnominal but not in prenominal RCs lends further support for a raising analysis of the former variant.

\subsubsection{Weak island sensitivity}

Our third diagnostic tests whether RCs display sensitivity to weak islands, which we assume is indicative of $\bar{A}$-movement. In the case at hand, Head-raising is predicted to invariably be sensitive to (certain) islands. In contrast, in matching $\mathrm{RCs}$ island effects are only predicted to be present if the relevant structure involves some type of $\bar{A}$-movement, either of the internal Head or of a null operator (on the variable behavior of matching relatives in the context of syntactic islands, see Cinque 2008a: 12). Cinque (2015: 15, referring to Rizzi 1990) illustrates this point with English RCs whose Head is a (necessarily non-referential) measure phrase, which are independently known to behave like Head-raising structures. As illustrated in (23b), relativization across three different types of island boundaries results in ungrammaticality.

(23) (a) John weighed 200 lbs.

(b) * The $200 \mathrm{lbs}$

(i) that I wondered whether he weighed.

(wh-island)

(ii) that he did not weigh in his youth would be too much.

(negative island)

(iii) that I am glad that he weighs would be too much for me. 
In PhG, prenominal and postnominal RCs differ with respect to weak island sensitivity. While the gap corresponding to the Head of a postnominal RC cannot be contained inside a $w h$-complement clause - a weak island (Cinque 1990, Rizzi 1990) (24a), a configuration of this type is tolerated in prenominal RCs (24b), showing that this structure is immune to weak island effects.
(a) $*[\mathbf{O}$
tópus
[tu rótsa
ta
DET.M.NOM.SG field.M.NOM.SG TU ask.PST.1SG 3OBJ
[tuz xa nási how PRT plow.3SG
]]] čav sérti íni.
very rough.SG COP.3SG
(b) [[Tu rótsa TU ask.PST.1SG 3OBJ how PRT plow.3SG

o tópus] čav sérti íni.
DET.M.NOM.SG field.M.NOM.SG very rough.SG COP.3SG
'The field that I asked him how he would plow is rather rough.'

The contrast between (24a) and (24b) again suggests that only postnominal RCs involve $\overline{\mathrm{A}}$-movement (of the Head).

\subsubsection{Amount relatives}

Our final diagnostic concerns amount relatives. Amount relatives are a type of maximalizing RC (in the sense of Grosu \& Landman 1998), in which the Head is characterized as 'sortal-internal': in other words, it is always interpreted RCinternally, and is semantically interpreted as a degree variable (Carlson 1977, Heim 1987, Grosu 1994, Grosu \& Landman 1998 a.o.). Amount relatives further involve an operation of maximalization at the level of clause, which ensures that the Head is interpreted as a set of amounts, rather than a set of individuals. Consider the example in (25a), whose rough LF representation is given in (25b).

(25) (a) No linguist would read [ the many books [ that/Ø Gina will need for vet school]]. (adapted from Sauerland 1998: 64 his (54))

(b) No linguist would read $\max [\lambda d$.Gina will need [ $d$ many books] for vet school]. 
Because the Head in amount relatives is always interpreted RC-internally (irrespective of its surface position), these RCs can be characterized as bona fide raising structures (Cinque 2015).

In PhG, an amount reading of the RC Head emerges only in postnominal RCs (26a): 'There is a number $n$ such that Nerkiza read $n$-many books (to become a doctor) and no one can read the identical $n$-many books (and become a doctor)' - the 'set of individuals' reading also being available for this example ('there is a set of books $\sigma$, such that Nerkiza read $\sigma$ (to become a doctor) and no one can read the identical $\sigma$ (and become a doctor)'). In contrast, in prenominal RCs (26b) the Head unambiguously denotes a set of individuals, suggesting that reconstruction of the Head is not possible in this structure.

(26) Kanís čo porí na Jiavási no one.NOM not can.3SG PRT read.3SG

(a) [ta puyá ta vivlía [tu

AGR.PL many DET.N.ACC.PL book.N.ACC.PL TU preftínkin na Jiavási i Nerkíza

have to.PST.3SG PRT read.3SG DET.F.NOM.SG Nerkiza.F.NOM.SG

_ ] na íni xekím tejí.

PRT become.3SG doctor.M.NOM.SG COMP

(b) [ [ tu preftínkin na ðiavási i

TU have to.PST.3SG PRT read.3SG DET.F.NOM.SG

Nerkíza _ ] ta puyá ta

Nerkiza.F.NOM.SG AGR.PL many DET.N.ACC.PL

vivlía] na íni xekím tejí.

book.N.ACC.PL PRT become.3SG doctor.M.NOM.SG COMP

'No one can read the many books that Nerkíza had to read to become a doctor.'

\subsubsection{To sum up}

The differences between pre- and postnominal RCs are summarized in Table 2. Our main conclusion is that the two patterns do not simply differ in terms of linear word order but also with respect to their internal syntax: the postnominal variant displays connectivity effects, indicative of a raising derivation, whereas 


\begin{tabular}{lll}
\hline & Postnominal & Prenominal \\
\hline 1. O-relativization in V+ O idioms & YES (19a) & NO (19b) \\
2. Scope reconstruction (Q $>$ Num) & YES (22a) & NO (22b) \\
3. Weak island sensitivity & YES (24a) & NO (24b) \\
4. Amount reading & YES (26a) & NO (26b) \\
\hline
\end{tabular}

Table 2

Differences between pre- and postnominal RCs in PhG.

prenominal RCs do not. The latter are therefore better characterized as matching structures.

This conclusion implies that there is not one 'primary relativization strategy' (in the sense of Keenan \& Comrie 1977) in present-day $\mathrm{PhG}$, and that one type of HRC is not derived from the other via preposing/left dislocating the Head or extraposing the RC. Apart from the structural differences reviewed so far, the lack of semantic/pragmatic differences between the two patterns also confirms this claim.

\subsection{Towards a structural analysis}

Returning to the syntax of HRCs in $\mathrm{PhG}$, we propose that the derivation of a prenominal RC like (14) is as in (27). In this structure, neither of the Heads evacuates its base position, and the external Head $\mathrm{dP}_{1}$ triggers backward deletion of the internal Head $\mathrm{dP}_{2}$. Since the overtly spelled out Head is the external one, the lack of connectivity and island effects, as well as the word order, are correctly accounted for. 
(27)

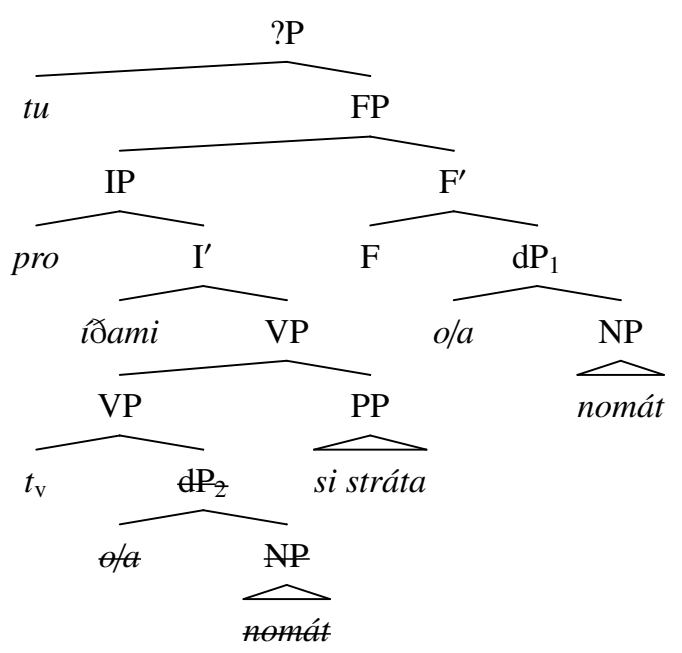

Two remarks are in order. First, in (27) we are being deliberately vague about the functional superstructure above FP (i.e. the base position of the RC), and by this token also about the position of the relativizer $t u$ : these two issues will be addressed in Section 5. Second, we assume that the article accompanying the external Head is the overt spell-out of $d_{1}$ (which in a language like English is not lexicalized overtly), and not of an external D-category scoping over the entire complex nominal. Without going into full detail, following Lekakou \& Karatsareas (2016) we analyze this low determiner as a semantically vacuous expletive article, lexicalizing a nominal class feature rather than a contentful definiteness head. See also Revithiadou \& Spyropoulos (2012: 107) for related discussion concerning a variety of Pontic Greek.

Turning to postnominal RCs (15), we propose that these are derived as in (28). This structure involves movement of the internal Head to $\mathrm{SpecCP}_{2}$, from where it deletes the external Head under c-command. Given that the overt Head has undergone $\bar{A}$-movement, reconstruction effects and weak island sensitivity are both correctly predicted to be available. 
(28)

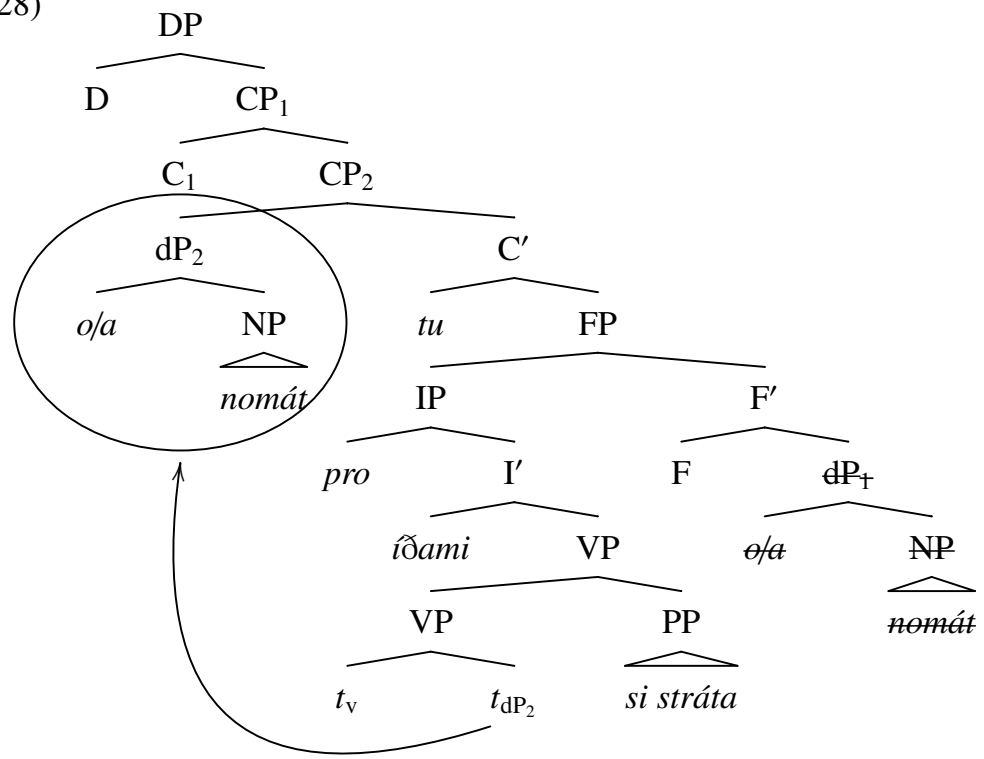

Having completed our synchronic analysis, we now turn to the origins of prenominal and postnominal RCs in PhG. Our three main explananda will be (i) the difference qua constituent order, (ii) the different derivations underlying the two patterns (matching vs. raising), and (iii) the morphological shape (i.e. the etymology) of the relativizer $t u$. To lay the groundwork, we first give a brief overview of relativizers and relativization strategies in the history of Greek, with special reference to the period from post-Classical Greek onwards.

\section{A BRIEF OVERVIEW OF RELATIVIZATION IN THE HISTORY OF GREEK}

In the history of Greek, many different relativization strategies have been available. Here we will only discuss those structures that are most relevant for diachronic reconstruction coming up in Section 5. For more detailed discussion, we refer to Probert (2015) (on Archaic Greek), Jannaris (1987[1897]: 352-355, 468-471) and van Emde Boas et al. (2019: 563-579) (on Classical Greek), Mayser (1934: 98-113), Bakker (1974), Kriki (2013), Bentein \& Bağrıç̧ı (2018) (on post-Classical Greek), Kirk (2012: 77-224) (on New Testament Greek), and to Browning (1983: 66-67), Chila-Markopoulou (1990/1991), Liosis \& Kriki 
(2014), and Holton et al. (2019: 1091-1164, 1983-1992) (on Medieval Greek). For general diachronic overviews, see Nicholas (1998b) and Manolessou (2004).

Leaving aside internally-Headed RCs (which are not directly relevant for our discussion of $\mathrm{PhG}$ ), in the following two sections we introduce the most important types of postnominal and prenominal RCs that have been available in the history of Greek. In both types, the relationship between the Head and the RC-internal gap is either mediated by an agreeing relative pronoun or article, or by an invariant relativizer. We first discuss postnominal relatives.

\subsection{Postnominal RCs}

\subsubsection{Agreeing relativizers}

The most common relativization strategy in Archaic, Classical and Early Medieval Greek involves postnominal RCs introduced by a clause-initial relative pronoun (see Table 3 ). These pronouns agree in number and gender with the Head, and is typically case-marked inside the RC. Two examples with relative pronouns are given in (29).

\begin{tabular}{clllllll}
\hline & \multicolumn{3}{c}{ Singular } & \multicolumn{3}{c}{ Plural } & Dual \\
& M & F & N & M & F & N \\
\hline NOM & hós & hé: & hó & hoí & haí & há & hó: \\
ACC & hón & hé:n & hó & hoús & hás & há & hó: \\
GEN & hoû & hê:s & hoû & hô:n & hô:n & hô:n & hoîn \\
DAT & hô:i & hê:i & hô:i & hoîs & haîs & hoîs & hoîn \\
\hline
\end{tabular}

Table 3

Ancient Greek relative pronouns.

(29) (a) enétyk ${ }^{\mathrm{h} o ́ n}$ soi perì [ tềs ónu appeal.PST.1SG you.DAT about DET.F.GEN.SG she-ass.F.GEN.SG mu [hèn élaben Nikías]]. my RP.F.ACC.SG take.PFV.3SG Nikias.M.NOM.SG 'I made a petition to you about my she-ass which Nikias took.'

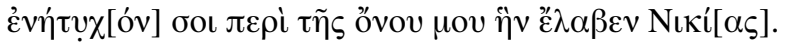

(p.mich, 1.29. 1-2 (256 всЕ)) 
(b) $[\ldots]$ épese ce $[\mathbf{i}$ lóyxi

fall.AOR.3SG and DET.F.NOM.SG spear.head.F.NOM.SG

[in ekráti to áyalma]] [...]

RP.F.ACC.SG hold.IPFV.3SG DET.N.NOM.SG statue.N.NOM.SG

'[...] the spear-head that the statue was holding also fell down [...]'

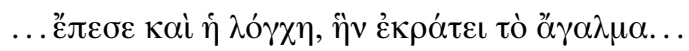

(Chr., 18.118. 18-19 (6th c. CE))

Relative pronouns, which were in use as late as Late Medieval Greek (mostly in higher registers, Holton et al. 2019: 1123) do not survive in any Modern Greek variety. $^{14}$

Relative articles also show number and gender agreement with the Head. They are morphologically identical to definite articles, with the proviso that masculine and feminine nominative forms (cf. the shaded cells in Table 4) of relative articles are not attested (Bakker 1974: 63-68, Manolessou 2004: 6-7; but see Holton et al. 2019: 1097 fn. 96 for two dubious exceptions). These relativizers also appear at the left edge of the RC.

\begin{tabular}{llllllll}
\hline & \multicolumn{3}{c}{ Singular } & \multicolumn{3}{c}{ Plural } & Dual \\
& $\mathrm{M}$ & $\mathrm{F}$ & $\mathrm{N}$ & $\mathrm{M}$ & $\mathrm{F}$ & $\mathrm{N}$ & \\
\hline NOM & ho & he: & tó & hoi & hai & tá & tó: \\
ACC & tón & té:n & tó & toús & tás & tá & tó: \\
GEN & toû & tê:s & toû & tô:n & tô:n & tô:n & toîn \\
DAT & tô:i & tê:i & tô:i & toîs & taîs & toîs & toîn \\
\hline
\end{tabular}

Table 4

(Ancient) Greek definite and relative articles.

An example of a postnominal RC with a relative article is provided in (30) (for additional illustrations, see Gignac 1981: 179, Kriki 2013: 291-297 and Holton et al. 2019: 1099-1103).

(30) [Tin Gálasan [tin me éferes $][\ldots]$

DET.F.ACC.SG sea.F.ACC.SG RA.F.ACC.SG I.ACC bring.IPFV.2SG

[14] Other relative pronouns include emphatic ósper and the indefinites óstis and opoíos, which we here leave aside. 
'The sea (that) you brought to me...'

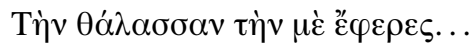

(Prodr., 1.58, (12th c. cE))

Outside the Attic dialect relative articles are attested only sporadically in Ancient and Classical Greek (Manolessou 2004: 6), but they are more common in papyri from the post-Classical period. They are also frequently found in Early Medieval Greek chronicles and hagiographical texts, and they are the most frequently used device to introduce RCs in Late Medieval Greek (Browning 1983: 62, ChilaMarkopoulou 1990/1991: 32). They start to become rarer from the 16th c. onwards (Holton et al. 2019: 1097). Nominative/accusative neuter singular and plural forms of the relative articles are preserved as fossilized relativizers in certain iAMG varieties. In (31) we illustrate forms deriving from tó an tá from the present-day Cappadocian variety of Misti, where through application of standard phonological processes they appear as $d u$ (sg.) and $d a(\mathrm{pl}$.$) :$
(a) $[[d u$ yórais $]$
du
pasturmás]
RA.SG buy.PST.2SG DET.N.NOM.SG pastrami.N.NOM.SG 'the pastrami that you bought'

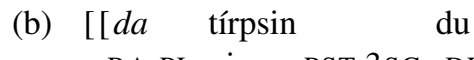
RA.PL pierce.PST.3SG DET.N.NOM.SG child.N.NOM.SG
$\mathrm{du} \quad \mathrm{fšax}]$
da yabáxa]
DET.N.NOM.PL pumpkin.N.NOM.PL
'the pumpkins that the child pierced'
(Cappadocian Greek, Misti variety; T. Papanikolaou, p.c.)

\subsubsection{Invariant complementizers}

Around the 5th c. CE a new relativization strategy emerged, involving the indeclinable relativizer $(o ́) p u$, which derives from the locative relative pronoun (h)ópu 'where'. It becomes very frequent as a generic relativizer after the 12 th $\mathrm{c}$. CE (Nicholas 1998b: 200-211) (32a) and survives as the most common relativizer in Standard Modern Greek (32b) and in various non-standard varieties (Nicholas 1998b: 50-53, 506-536 App. B) 
(a) [...] lavóntes ce [ton aðelfón bring.PTCP.AOR.PL and DET.M.ACC.SG brother.M.ACC.SG [о́ри íçe proz atón din PU have.IPFV.3SG towards he.ACC DET.F.ACC.SG lípin]] [...]

pain.F.ACC.SG

'... bringing the brother who had distressed him...'

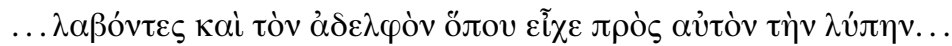
(Apophth., 65:300B, $\beta^{\prime}, 28-29$ (6th c. CE))

(b) $[\mathbf{O}$ kaقijitís $[p u$ mas ékane

DET.M.NOM.SG teacher.M.NOM.SG PU we.ACC do.PST.2SG istoría] $\quad[\ldots]$

history.F.ACC.SG

'The teacher who taught us history ...'

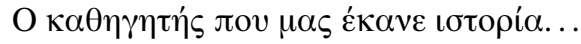

(Modern Greek, cited in Holton et al. 2012[1997]: 532 their (1a))

Another indeclinable relativizer is $u$, which derives from the masculine/neuter genitive singular of the relative pronoun (hô, cf. Table 3). It often functions as a locative relativizer (33a) (though this use becomes rarer after New Testament Greek, Nicholas 1998b: 201), and after prepositions which canonically take genitive complements such as prin 'before', éos 'until', apó 'since', ek 'from' and méxri 'until (33b), especially in post-Classical Greek (Kriki 2013: 209235, Bentein \& Bağrıaçık 2018). Importantly, there is some evidence that $u$ can also appear as a generic relativizer in contexts where it has apparently lost the semantics of a genitive or locative, especially in Medieval Greek (33c). ${ }^{15}$
(a) $[\ldots]$ elálesan
en $[$ te
póli
$[u$
speak.AOR.3PL in DET.F.DAT.SG town.F.DAT.SG U
o proph $^{\mathrm{h}}$ etes o
DET.M.NOM.SG prophet.M.NOM.SG DET.M.NOM.SG presbýtes katóki en a $\phi^{\mathrm{w}}$ tẹ]]. old.M.NOM.SG settle.IPFV.3SG in it.F.DAT.SG '... they spoke in the town wherein the old prophet lived.'

[15] Besides HRCs and adverbial clauses, $u$ could also introduce argumental FRCs (Kriki 2013: 211). 


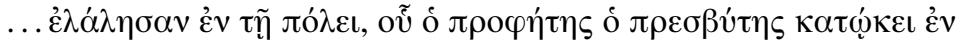

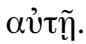
(LXX, Reigns III, 13.25 (2nd c. BCE-1st c. CE))

(b) $[\ldots]$ prin $[u$ is ta áno méri before $\mathrm{U}$ in DET.N.ACC.PL upper side.N.ACC.PL apél $\theta \mathrm{i}]$. come.AOR.SBJV.3SG

'... before he goes up the country.'

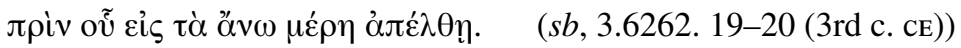

(c) [...] eklironómisén se [akrivá bequeath.PST.3SG you.ACC.SG expensive.N.ACC.PL práymata $[u \mathrm{u}$ f0íronde $]$.

thing.N.ACC.PL U not wear down.PASS.3PL '... he bequeathed you expensive things which do not become worn out.'

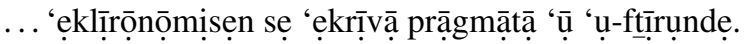

(H. Porte, 31b. 2c-3c (15th. c. CE), cited in Liosis \& Kriki 2013: 264 their (35))

$U$ does not survive as a generic relativizer in any Modern Greek dialect today; however, in Pontic Greek it is preserved as a suffix in the relativizer úts- $u(<o$ otis $+u$ 'whoever'), where it functions as a reinforcer (Liosis \& Kriki 2013: 254, 261). Elsewhere, it survives in PhG in the (lexicalized) adverbial conjunction samú '(the moment) when', which probably goes back to a combination of ísame 'until' and $u$. Alternatively, as a reviewer suggests, it may be a combination of sáma 'when' (claimed to be attested in PhG by Karolidis (1885: 128), although we did not encounter the form in our corpora) and $u$. In Standard Modern Greek, it appears in (archaicizing) lexicalized conjunctions like afú 'after, since' $(<$ apó 'since $+u)$ and $e k s u ́(k e)$ 'hence' $(<e k$ 'from' $+u)$.

\subsection{Prenominal RCs}

The range of possible relativizers is essentially the same in prenominal as in postnominal RCs. Below we give examples of prenominal RCs with a relative 
pronoun (34) and a relative article (35). ${ }^{16}$

ek yar [[on épempsas] drak $\left.^{\mathbf{h}} \mathbf{m o ́ n}\right][\ldots]$

from PRT RP.F.GEN.PL send.AOR.2SG drachma.F.GEN.PL

'From the drachmae that you sent...'

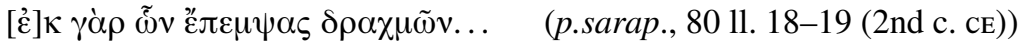

[ [ tus yar épempsás my] tris statíras] pálin

RA.M.ACC.PL PRT send.AOR.2SG I.DAT three stater.M.ACC.PL again sy điepemsámin.

you.DAT.SG send off.AOR.1SG

'I send you the three staters which you have sent me.'

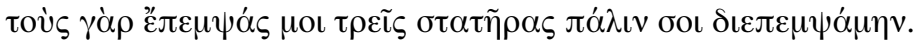

(p.oxy., 14, 1765 11. 10-13 (3rd c. cE))

Prenominal RCs have been analyzed as internally-Headed RCs (Kriki 2013, Fauconnier 2014, Probert 2015). However, it is not clear whether this analysis is justified for examples like (34)-(35), for which a Head-external parse is indeed plausible, given that the Head canonically receives case from a case assigner in the matrix clause, not from a source within the RC. For further discussion of Headexternal prenominal structures in post-Classical Greek, see (Bentein \& Bağrıaçık 2018). We now turn to the genesis of the $\mathrm{PhG}$ relative complementizer $t u$.

\section{THE ORIGINS OF PRENOMINAL RCS IN PHG}

\subsection{Decomposing tu as ' $\mathrm{D}+\mathrm{C}$ '}

Concerning the etymology of PhG $t u$, the standard view is that it is a fossilized form of the masculine/neuter singular form of the relative article (Favis 1948: 191, Anastasiadis 1976: 169, Nicholas 1998b: 295). However, as noted in Liosis \& Kriki (2013: 264), there are certain problems with this analysis. For one thing, there is no $[\mathrm{o}]>[\mathrm{u}]$ raising in monomorphemic words in $\mathrm{PhG}$, making it phonologically unlikely that $t u$ is related to $t o$. In addition, $t u$ is used consistently

[16] (34) additionally exhibits case attraction, i.e. the phenomenon whereby a declinable relativizer bears the same case as the Head (on case attraction in various stages of the Greek language, see Probert (2015: 167-198), Rijksbaron (1986: 238-241) and Bentein \& Bağraçık (2018). 
for both singular and plural Heads in PhG: in this respect, it contrasts with many other iAMG sub-varieties where (remnants of) both singular and plural relative articles are preserved (see Janse to appear: §7.4.6, Oeconomides 1958: 243 and Costakis 1968: 75 for the dialects of Cappadocia, Pontus (Ano Amisos variety) and Silli respectively).

As an alternative, we build our analysis on the idea that 'tu derives from the generic complementizer $u$ with the analogical addition of $t$-', $^{\prime}$ attributed by Liosis \& Kriki (2013: 264) to Christos Tzitzilis. ${ }^{17}$ We explore the hypothesis that the oldest instantiations of $t u$ are composed of the $t$ - segment of the definite article (i.e,. a form of the article that starts with a $/ \mathrm{t} /$ and whose final vowel is elided), and the generic complementizer $u$. We believe this alternative is potentially more explanatory than an analogy-based account, which so far has not received any independent support.

Concretely, we propose that $t u$ came into being through reanalysis of a linear string in which a determiner built on a $t$-stem (with elision of the final vowel) and the generic relativizer $u$ are adjacent, rather than through analogy. The abstract schema of the input structure for the proposed reanalysis is as in (36a). (36b) is the concrete realization of this pattern, which we assume gave rise to the emergence of $t u$.

$$
\begin{aligned}
& \text { (a) }\left[{ }_{\mathrm{DP}} \operatorname{DET}\left[{ }_{\mathrm{CP}} \mathrm{C}\right]\right] \\
& \text { (b) }\left[{ }_{\mathrm{DP}} t(\mathrm{~V})\left[{ }_{\mathrm{CP}} u \ldots\right]\right]
\end{aligned}
$$

There are two environments in which the exponent of an external D position and a relativizer inside the $\mathrm{RC}$ can be string-adjacent, namely prenominal RCs with a leftward definite determiner (definite article), and light-Headed relatives

[17] Nicholas (1998b: 295 fn. 40) ) considers yet another possibility: '[...] $t u$ may have derived $[\ldots]$ from the genitive singular neuter definite article tô, which was in use in [post-Classical, Medieval] Greek as a complementi[z]er preceding the infinitive (e.g. et $^{h}$ élo: tou elt $^{h}$ ên 'I.want of.the to.come = I want to come') (reference omitted).' On infinitives preceded by tôे, see also Joseph (1983: 49). According to Nicholas, this account requires that ' $[\ldots]$ tu should have developed independently in [PhG] from the rest of [ inner Asia Minor] Greek.' We agree with the author and consider it unlikely that the use of the infinitival (and thus in a sense nominal) complementizer $t u$ was extended to (also) serve the very different purpose of introducing RCs. 
(i.e. RCs headed by a demonstrative (or a bare quantifier, not relevant here), cf. Citko 2004):
(a) $\left[\mathrm{DP}\right.$ DET $\left.\left[\mathrm{CP}_{\mathrm{C}} \mathrm{C}\right] \mathrm{Head}\right]$
(b) $[\mathrm{DP} \operatorname{DEM}(/ \mathrm{Q})[\mathrm{CP} C \ldots]]$

Although prenominal RCs without a determiner and 'bare' FRCs are the norm, the two structures in (37) have been available since the Homeric period as a minority pattern. ${ }^{18}$

In Archaic Greek the element that later becomes the definite article clearly retains (some of) its original demonstrative force (Probert 2015: 137). (38) is an example from Homer where the relevant D-category is followed by a relative pronoun:

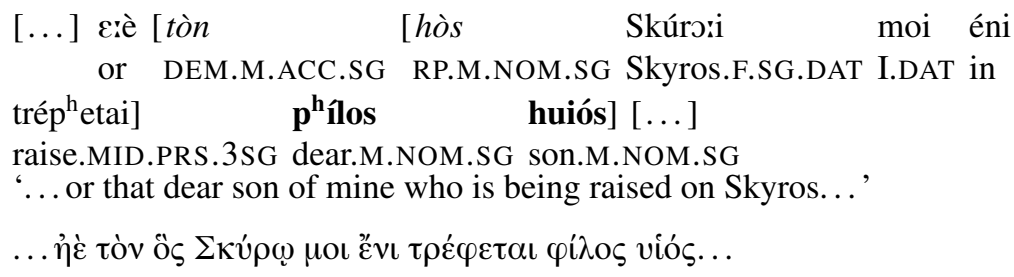

(Il. 19.326 (8th c. BCE), cited in Probert 2015: 137 her (6.27))

The same 'D + relative C' pattern is also attested in Classical (39a) and postClassical (39b) periods, when the definite article had lost all its demonstrative semantics to become a pure marker of definiteness (see Anagnostopoulos 1922: 188 and Bentein \& Bağrıaçık 2018 for further examples).
(a) $[\ldots][t \hat{\varepsilon}: i$
$[h \hat{\varepsilon}: i$
$\mathrm{p}^{\mathrm{h}} \mathrm{\dot { \varepsilon }}$ is
sỳ]
DET.F.DAT.SG RP.F.DAT.SG say.PRS.2SG you.SG.NOM skle:róte:ti]
skle:róte:s
'... in the (word) sklerótes ('hardness') that you mention...'

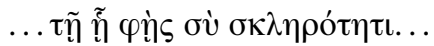
(Crat., 435A (4th c. BCE))

[18] Crucially, despite the absence of a definite article, the Head of these prenominal RCs always receives a definite interpretation (Kriki 2013: 222-223, Fauconnier 2014). 
(b) $[\ldots]$ menónton sy [ton

remain.PTCP.PRS.GEN.PL you.DAT.SG DET.F.GEN.PL

[hon op ${ }^{\text {hílo }} \quad$ sy] drak $^{\mathbf{h}}$ món

RP.F.GEN.PL owe.PRS.1SG you.DAT.SG drachma.F.GEN.PL

$\mathbf{k}^{\mathbf{h}}$ ilíon].

thousand.GEN

'... the 1000 drachmae that I owe you remain for you.'

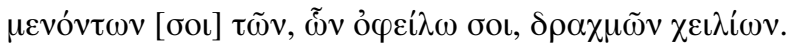

(bgu 1.69. 15-17 (2nd c. ce)

Finally, there are also numerous examples featuring the relevant ' $\mathrm{D}+$ relative C' sequence from Medieval Greek (see Jannaris 1987[1897]: 321, Nicholas 1998a and Holton et al. 2019: 1128-1129, 1135-1138). We therefore conclude that the structure in (36a) was indeed available.

\subsection{Syntactic reanalysis, lexical innovation, and their consequences}

We would like to propose that $t u$ came into being when language learners analyzed a linear string consisting of a definite article of the form $t(V)$ and the complementizer $u$ as a single lexical item. This means that ' $t(V)+u$ ' sequence, realizing (36b) must have occurred in Greek at a time before this reanalysis, similar to more frequently occurring ' $D+$ relative $C$ ' sequences discussed in Section 5.1 Though scarce, evidence for the fact that this was indeed the case exists, as in (40):

(40) ce perí $\left[\right.$ to $u \mathrm{k}^{\mathrm{h}}$ orís $\left.\{\ldots\}\right]$

and about DET.N.SG U without

'... and about that which without (?)...'

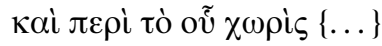

(bgu. $3.865114,2$ nd c. CE)

The fragmentary nature of the papyrus from which (40) was extracted does not allow us immediately to reconstruct a full clause thus we cannot decisively conclude whether it instantiates a prenominal $\mathrm{RC}$, a light headed $\mathrm{RC}$ or an adverbial clause. Nevertheless, it does show that the ' $t(V)+u$ ' sequence was available in what seems to be a subordinate clause.

This process of morphological fusion had an immediate effect on the possible 
positions of the overt Head in HRCs: the specifier positions associated with the C-positions in between the external determiner and the head hosting $u$, which could otherwise host the displaced internal or external Head, or a remnant IP were suppressed (41). Instead, the only option to form HRCs with the newly formed relativizer $t u$ involves spell-out of the external Head $\mathrm{dP}_{1}$ in its base position, with backward deletion of the internal Head $\mathrm{dP}_{2} \cdot{ }^{19}$ This gives rise to an externally Headed prenominal RC of the matching type, in which the bimorphemic lexical item $t u$ heads a projection which syncretically encodes both a C- and a Dfeature. $^{20}$

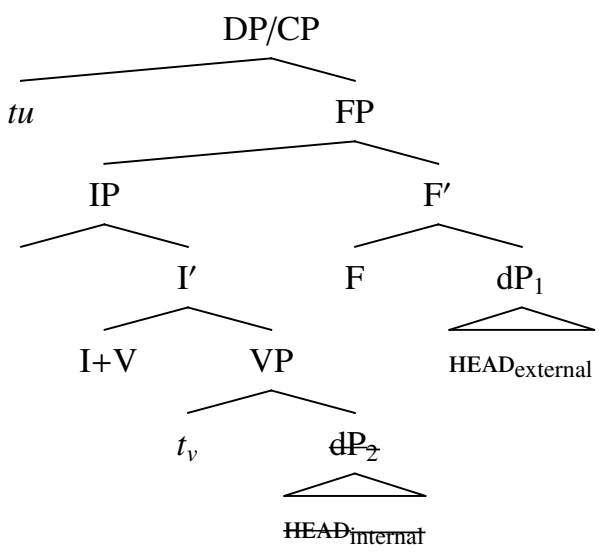

The earliest clear examples in which the relativizer $t u$ appears as a single word that we could find are given in (42)-(43), both from the 3th c. cE. (42) is a FRC and (43) is a prenominal RC. As the bracketing indicates, the structure we assume for (43) is exactly the one detailed in (41): ${ }^{21}$

[19] Another option is the spell-out of the internal Head $\mathrm{dP}_{2}$, with forward deletion of the external Head $\mathrm{dP}_{1}$. This process could be at work in the rare cases of internally-Headed RCs observed in texts before and shortly after 1923 (see Section 2.1).

[20] The claim that two functional heads can be spelled out syncretically is reminiscent of Rizzi's (1997: 312) proposal that the heads Force and Fin form one complex head (not formed through head movement) in the absence of any left-peripheral XP intervening between the two. Crucially, in our case syncreticization is enforced through the feature composition of $t u$, without it being possible to break up the relevant unit by projecting additional structure. On the alternation between syncretic and 'scattered' spell-out of functional categories, see also Giorgi \& Pianesi (1997).

[21] Recall from Section 1.3 that the only difference between FRCs and HRCs is that the former 
[...] my enetílato [tu sy Jiló] [...]

I.DAT assign.AOR.3SG TU you.DAT.SG disclose.PRS.1SG

'... He assigned me (everything/the things) which I disclose to you...'

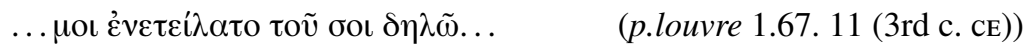

[...] eán andipémpsis my [ [tu píisás my
if send.back.SBJV.2SG I.DAT

oӨoníðja].

linen cloth.N.ACC.PL

'... if you send back to me the linen clothes which you made for me.'

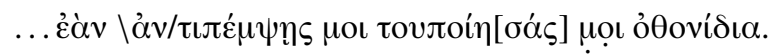

(p.oxy 20, 2273. 16 (3rd c. cE), cited in Kriki 2013: 293 her (16))

Crucially, we have encountered no early (dating from before the 7th c. CE) examples of postnominal RCs with $t u$, in which $t u$ is not a genitive singular of the masculine/neuter relative article, neither in the existing literature (see e.g. Kriki 2013: 291-310, Holton et al. 2019: 1097-1105) nor in our own additional corpus searches. ${ }^{22}$ This absence can naturally be accounted for given

feature two silent Heads, (viz. classifier-like elements such as PERSON/PEOPLE or THING(S)). These are not expected to block fusion of $t$ - and $u$ when intervening between these two elements. A potential problem with our account for the emergence of $t u$ is that FRCs are commonly analyzed as involving maximalizing semantics, and thus they are claimed to be derived through Head-raising (Grosu \& Landman 1998, Caponigro 2003). Since the suppression of SpecCP in our account entails that Head-raising becomes unavailable, it would not be possible to derive the inherently maximalizing nature of FRCs. However, FRCs with $t u$ in PhG do not qualify as bona fide maximalizing structures, given that they can receive an existential interpretation, namely when complementing verbs with existential import (i). Existential FRCs (on which see Caponigro 2003 and Cinque 2020: $\$ 2.5 .5$ ) are obviously non-maximalizing. Structures like (i) differ from FRCs involving a relative pronoun, such as óti 'what(ever)', which are inherently maximalizing and thus unable to function as existential FRCs (ii):

(i) čo íxa [tu na ipó].

not have.PST.1SG TU PRT say.1SG

'I did not have anything to say.'

(ii) * *co íti na ipó].

not have.PST.1SG RP.ACC PRT say.1SG

int.: 'I did not have anything to say.'

[22] The following example may be one of the first attestations of the relevant pattern:

(i) $[\ldots]$ ítisa $[\ldots]$ piíse $\quad[$ to $\quad$ ospítin $\quad$ tu request.AOR.1SG make.AOR.INF DET.N.ACC.SG house.N.ACC.SG TU emis $\theta$ óso] $][\ldots]$

rent.FUT.1SG

'... I requested ... that I build the house which I will rent out...'

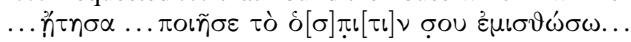


the scenario just outlined, but remains puzzling if we assume that $t u$ was originally a (monomorphemic) relative article, as suggested by Anastasiadis (1976) and Nicholas (1998b): we do not see why no early postnominal RC with $t u$ should survive, not in the least because postnominal RCs with relative articles abound in the history of Greek (see a.o. Liosis \& Kriki 2014).

On the basis of the hypothesized structure (41), exemplified in (43), we can make one important prediction concerning the structure of (early) prenominal RCs with $t u$, namely that the Head should always be interpreted as definite (by virtue of $t$-'s D-feature), despite it not appearing with a definite article (which would compete with $t u$ for the same structural position). This is indeed what is canonically the case with prenominal RCs in historical Greek (see footnote 18). ${ }^{23}$ However, as stated in sections 2.1 and 2.2, in PhG the Head of a prenominal RC must be accompanied by what is traditionally called a definite determiner, which we earlier suggested are expletives rather than genuine definiteness markers (cf. Section 3.2). Alternatively, it can be accompanied by an indefinite determiner. Two relevant examples are given in (44).
(a) [ [Tu 1ðami
$\mathrm{si}$
stráta]

TU see.PST.1PL on.DET.F.ACC.SG road.F.ACC.SG o

nomát $]$...

DET.M.NOM.SG man.M.NOM.SG

'The man we saw on the road...'

(b)

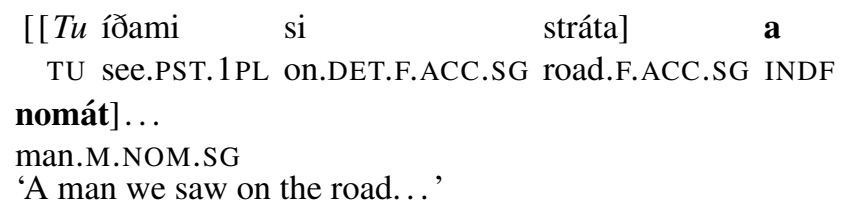

(p.bas 19. 2-4 (6th-7th c. CE), cited in Nicholas 1998b: 203 his (31c))

According to Kapsomenakis (1938: 99 fn. 2), reading $\sigma o \cup$ [su] as the second singular genitive pronoun 'your' does not make sense in this papyrus. Based on this, Nicholas (1998b: 203) claims that ọou should be read as tou [tu], yielding a postnominal HRC: (i) appears much later than (43), and as we will show below, there is nothing that precludes postnominal RCs with $t u$ once the amalgam $t u$ is treated as a monomorphemic complementizer, quite on the contrary. See also Trinchera (1865: 118-119 XC), where a number of postnominal RCs with $t u$ appear in a text (produced in Southern Italy) from the 12th c. CE.

[23] The definite reading of the FRC in (e41) also follows from this argument. 
We would like to suggest that the lack of a definiteness restriction on the Head emerged in $\mathrm{PhG}$ due to the fact that the original [+definite] feature associated with the $t$ - component of $t u$ was lost over time. In other words, $t u$ was further reanalyzed as a monomorphemic exponent of $\mathrm{C}$, leaving the external D-position available to be occupied by any type of non-overt determiner (definite or otherwise).

As to the conditions under which reanalysis took place, two factors may have contributed to this development. First, note that the semantic import of the definite determiner in HRCs and light-headed RCs such as (38)-(40) is not immediately clear, and in a sense superfluous (given that any NP with a prenominal RC was interpreted as definite anyway), especially once the determiner had lost its demonstrative force. A second factor is the relative scarcity of the 'D + relative C' pattern: as a result of this the relevant string may have been difficult for language learners to parse correctly, and they may have been prone to equate it to the more frequent determinerless prenominal RC pattern, at least in those contexts where the (morpho)phonological properties of the determiner (starting with $a / t$ / and ending with a vowel that can be elided) and the relativizer (which must start with a vowel) allow for a morphological merger to take place.

To conclude this section, note that the above analysis goes against the standard assumption that prenominal RCs in PhG (and other AMG varieties) emerged only due to long-lasting contact with Turkish, a language in which the primary relativization strategy is the prenominal one (Dawkins 1916: 201-203, Andriotis 1948: 48, Janse 1998b, 1999, Thomason 2001: 74). ${ }^{24}$ The simplest interpretation of this line of analysis would entail that prenominal RCs developed from the pre-existing postnominal pattern through word order borrowing from Turkish. Importantly, however, given this scenario the origin and nature of $t u$ remain unexplained. Instead, we take it that Turkish influence cannot be considered

[24] Favis (1948: 185) and Anastasiadis (1976: 174-175) also claim that the emergence of prenominal RCs should not solely be attributed to Turkish influence; however, these authors also do not explain the origins of $t u$. 
the sole trigger for the emergence of prenominal RCs - a conclusion reached independently by Liosis \& Kriki (2013: 265). This is of course not to say that we want to eliminate the role of Turkish influence on PhG HRCs altogether: we do believe that contact with Turkish 'exacerbate[d]/reinforce[d an] existing tendency' (à la Sitaridou 2014: 52) - namely the use of prenominal RCs.

\section{Postnominal RCs: STRUCTURE BORROWING From MOdern GREeK}

To conclude our diachronic analysis, in this section we propose that PhG postnominal RCs were modeled on Modern Greek postnominal RCs, by identifying $t u$ with the Modern Greek complementizer $p u$, the relativizer par excellence in this language. As the earliest attested examples of unambiguously postnominal tu-relatives in $\mathrm{PhG}$ are observed after the relocation of $\mathrm{PhG}$ speakers to Greece, this claim seems to have some initial plausibility. The growing number of postnominal RCs among today's $\mathrm{PhG}$ speakers can also be understood if we take into consideration that they are only heritage speakers of $\mathrm{PhG}$, and that the language they mostly use in daily life is Modern Greek. Crucially, we should also note that the overall Modern Greek influence on PhG must have started before the population exchange, through the introduction of elementary education in the region of Pharasa (Dawkins 1916: 33, Papadopoulos 2006: 178-179); nevertheless, contact with Modern Greek became certainly much more intensive after 1923.

Recall that Modern Greek restrictive RCs involving the bona fide complementizer $p u$ are postnominal (32b). HRCs with $p u$ (which do not involve resumption, on which see Kotzoglou \& Varlokosta 2005) have standardly been analyzed as raising structures (Alexiadou \& Varlokosta 1996, Alexiadou 1998). Hence, our claim that PhG postnominal RCs have been modeled on Modern Greek HRCs also provides a direct explanation for why postnominal RCs in $\mathrm{PhG}$ have a raising derivation (cf. Section 3).

There is one additional piece of evidence in support of our claim that postnominal RCs in PhG and Modern Greek are structurally highly similar. In 
prenominal $\mathrm{RCs}$ in $\mathrm{PhG}$, it is possible for constituents to be fronted from within the RC to a position before $t u$ (Anastasiadis 1976: $2524 . \alpha^{\prime}$ ). For example, in (45) the PP se ména 'to me' appears to the left of tu:
[Se ména [[tu čo ftáni]
to
isáni]]
to I.ACC TU not molest.3SG DET.N.NOM.SG person.N.NOM.SG
na sósi puá xrónes
PRT live.3SG many year.F.ACC(?).PL
'May the person who does not molest me live many years.'

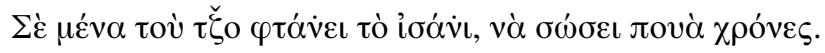

(Loukopoulos \& Loukatos 1951: 45 §240)

Such fronted constituents are arguably located in a Topic position above C (along the lines of Rizzi 1997). Importantly, constituent fronting is ungrammatical in postnominal RCs. Examples such as those in (46), in which a constituent of the RC intervenes between the Head and $t u$, are never attested in the written or oral corpus, and are judged unacceptable by informants today:

$$
\begin{aligned}
& \text { \# [ To } \\
& \text { isáni } \\
& \text { [se ména [tu čo ftáni]]]... } \\
& \text { DET.N.NOM.SG person.N.NOM.SG to I.ACC TU not molest.3SG }
\end{aligned}
$$

The ungrammaticality of (46) may be ascribed to the fact that SpecCP is filled by the Head, or to there being no Topic position above $t u$ : we will not here decide between these two possibilities. The important point is that $\mathrm{PhG}$ postnominal RCs pattern with their Modern Greek counterparts in terms of the ungrammaticality caused by fronted constituents: in Modern Greek too, no constituent can be fronted from within the RC to a position above $p u$ (Roussou 2000: 78; (47) is her (18c) in slightly adapted from):

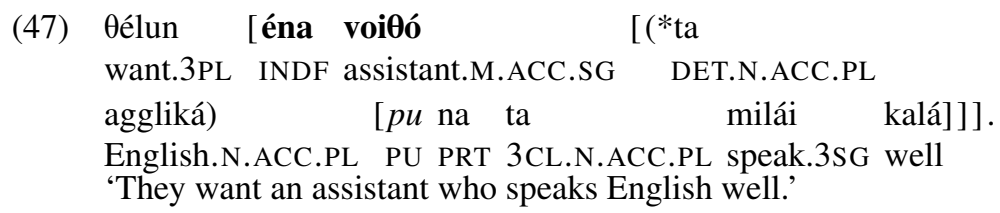

We would like to interpret this parallel behavior of PhG and Modern Greek to mean that postnominal RCs in the two languages are structurally similar. 


\section{SUMMARY AND CONCLUSIONS}

We have argued that prenominal and postnominal RCs in PhG have different structures and different origins. We first showed that postnominal RCs involve a raising derivation, whereas prenominal ones are of the matching type. Regarding the origins of the prenominal RCs, contrary to standard assumptions, we proposed that this structure did not emerge solely through contact with Turkish, but rather that it came about as a consequence of the morphological fusion of the exponents of an external determiner and invariant relativizer in a HRC structure, plausibly around the 3rd century CE. This morphological fusion eliminated SpecCP (or any other specifier positions between D and C) as a possible landing site for the internal (or the external) Head, leaving a prenominal matching derivation as the only option. According to our proposal, the role of Turkish influence consisted in fostering the pre-existing prenominal RC structure. To account for the relatively recent genesis of postnominal RCs, we proposed that language change was actuated through contact with Modern Greek. This claim was based on two characteristics common to both Modern Greek and PhG postnominal RCs: both are of the raising type and neither allow for constituent fronting. Our paper thus not only gives a diachronic explanation of two types of HRCs in $\mathrm{PhG}$ which correctly predicts their synchronic structural peculiarities, it also lends support to the claim that both matching and raising derivations for RCs must be acknowledged, even within a single language.

\section{TEXTS}

Apophth. $=$ Apophthegmata patrum . Edition: Migne, Jacques-Paul. 1864. Patrologiae cursus completus (series Graeca, 65). Paris: Migne.

Chr. = Ioannis Malalas, Chronographia . Edition: Thurn, Ioannes. 2000. Ioannis Malalae Chronographia. Berlin: De Gruyter.

Crat. = Plato, Cratylus. Edition: Burnet, John. 1903. Platonis opera . Oxford, UK: Oxford University Press.

H.Pforte = A Sublime Porte Textbook. Edition: Lehfeldt, Werner. 1989. Eine Sprachlehre von der Hohne Pforte. Ein arabisch-persisch-griechisch-serbisches Gesprächslehrbuch vom Hofe des Sultans aus dem 15. Jahrhundert als Quelle für die Geschichte der serbischen Sprache. Cologne \& 
Vienna: Böhlau Verlag.

LXX = Septuagint (Greek translation of Jewish Scriptures). Edition: Rahlfs 1971[1935]. Septuaginta,

1. Stuttgart: Württemberg Bible Society, 623-693.

Prodr. $=$ Poems of Poor Prodromos (Ptochoprodromika). Edition: Hesseling, Dirk-Christiaan \& Hubert Pernot. 1910. Poèmes prodromiques en grec vulgaire. Amsterdam: Johannes Müller.

\section{REFERENCES}

Alexiadou, Artemis. 1998. On the structure of Greek relative clauses. Studies in Greek Linguistics 18. $15-29$.

Alexiadou, Artemis \& Spyridoula Varlokosta. 1996. The syntactic and semantic properties of relative clauses in Modern Greek. ZAS Papers in Linguistics 5. 1-32.

Anagnostopoulos, Georgios. 1922. Peri tu arthru [On the determiner]. Athina 34. 166-247.

Anastasiadis, Vasilios. 1976. I sintaksi sto Farasiotiko idioma tis Kapadokias [The syntax of the dialect of Pharasa in Cappadocia]: University of Ioannina dissertation.

Andriotis, Nikolaos P. 1948. To glosiko idioma ton Farason [The dialect of Pharasa]. Athens: Ikaros.

Aoun, Joseph \& Yen-Hui Audrey Li. 2003. Essays on the representational and derivational nature of grammar: The diversity of Wh-constructions. Cambridge, MA: MIT Press.

Bakker, Willem. 1974. Pronomen abundans and pronomen coniunctum. A contribution to the history of the resumptive pronoun within the relative clause in Greek. Amsterdam: North-Holland.

Basilico, David. 1996. Head position and internally headed relative clauses. Language 72. 498-532.

Bağrıaçık, Metin. 2018. Pharasiot Greek: Word order and clause structure: Ghent University dissertation.

Bentein, Klaas \& Metin Bağraçık. 2018. On the third type of headed relative clause in Post-classical \& Early Byzantine Greek. Transactions of the Philological Society 116. 529-554.

Bhatt, Rajesh. 2002. The raising analysis of relative clauses: Evidence from adjectival modification. Natural Language Semantics 10. 43-90.

Bianchi, Valentina. 1993. An empirical contribution to the study of idiomatic expressions. Rivista di Linguistica 5. 349-385.

Bianchi, Valentina. 1999. Consequences of antisymmetry: Headed relative clauses. Berlin: Mouton de Gruyter.

Bowern, Claire. 2008. Linguistic fieldwork: A practical guide. New York: Palgrave Macmillan.

Brame, Michael. 1968. A new analysis of relative clauses: Evidence for an interpretive theory. Ms., MIT.

Browning, Robert. 1983. Medieval and Modern Greek. Cambridge, UK: Cambridge University Press.

Caponigro, Ivano. 2003. Free not to ask: on the semantics of free relatives and wh-words crosslinguistically: UCLA dissertation.

Carlson, Greg. 1977. Amount relatives. Language 53. 520-542.

Chila-Markopoulou, Despina. 1990/1991. Provlimata diachronikis sintaksis. I anaforikes protasis sti Meseoniki ke Nea Eliniki [Problems of diachronic syntax. Free relative clauses in Medieval and Modern Greek]. Glossologia 9-10. 13-42. 
Chomsky, Noam. 1965. Aspects of the theory of syntax. Cambridge, MA: MIT Press.

Cinque, Guglielmo. 1990. Types of A--dependencies. Cambridge, MA: MIT Press.

Cinque, Guglielmo. 1996. The antisymmetric programme: theoretical and typological implications. Journal of Linguistics 32. 447-464.

Cinque, Guglielmo. 2003. The prenominal origin of relative clauses. Presented at at the 'Workshop on Antysimmetry and Remnant Movement', New York University, October 31-November 1, 2003.

Cinque, Guglielmo. 2005. Deriving Greenberg's universal 20 and its exceptions. Linguistic Inquiry 36. 315-332.

Cinque, Guglielmo. 2008a. More on the indefinite character of the head of restrictive relatives. Rivista di Grammatica Generativa 33. 3-24.

Cinque, Guglielmo. 2008b. Two types of non-restrictive relatives. In Bonami d'Olivier \& Patricia Cabredo Hofherr (eds.), Empirical issues in syntax and semantics 7, 99-137. Paris: CNRS.

Cinque, Guglielmo. 2009. The fundamental left-right asymmetry of natural languages. In Sergio Scalise, Elisabetta Magni \& Antonietta Bisetto (eds.), Universals of language today, 165-184. Dordrecht: Springer.

Cinque, Guglielmo. 2015. Three phenomena between "raising" and "matching" relative clauses. Semantics-Syntax Interface 2. 1-27.

Cinque, Guglielmo. 2016. On the double-headed analysis of "headless" relative clauses. Ms., Ca'Foscari University of Venice,. lingbuzz/003224.

Cinque, Guglielmo. 2020. The syntax of relative clauses: A unified analysis. Cambridge, UK: Cambridge University Press.

Citko, Barbara. 2004. On headed, headless, and light-headed relatives. Natural Language and Linguistic Theory 22. 95-126.

Citko, Barbara. 2008. An argument against assimilating appositive relatives to coordinate structures. Linguistic Inquiry 39. 633-655.

Cole, Peter. 1987. The structure of internally headed relative clauses. Natural Language and Linguistic Theory 5. 277-302.

Costakis, Thanasis P. 1968. To glosiko idioma tis Silis [The dialect of Silli]. Athens: Center of Asia Minor Studies.

Dawkins, Richard. 1916. Modern Greek in Asia Minor: A study of the dialects of Síli, Cappadocia and Phárasa, with grammar, texts, translation and glossary. Cambridge, UK: Cambridge University Press.

Dawkins, Richard. 1940. The dialects of Modern Greek. Transactions of the Philological Society 39. $1-38$.

Dayal, Veneeta. 1997. Free relatives and 'ever'. Identity and free choice readings. In Devon Strolovitch \& Aaron Lawson (eds.), Proceedings from Semantics and Linguistics Theory VIII, 99-117. Ithaca, NY: Cornell University.

Deal, Amy. 2016. Cyclicity and connectivity in Nez Perce relative clauses. Linguistic Inquiry 47. 427-470.

van Emde Boas, Evert, Albert Rijksbaron, Luuk Huitink \& Mathieu de Bakker. 2019. The Cambridge grammar of Classical Greek. Cambridge, UK: Cambridge University Press. 
Fauconnier, Stefanie. 2014. Internal and external relative clauses in Ancient Greek. Journal of Greek Linguistics 14. 141-162.

Favis, Vasilis. 1948. Sintaktike paratirisis is to idioma ton Farason [Syntactic observations on the dialect of Pharasa]. Epetiris Vizantinon Spoudon 18. 173-191.

von Fintel, Kai. 2000. Whatever. In Brendan Jackson \& Tanya Matthews (eds.), Proceedings of SALT 10, 27-39. Ithaca, NY: CLC Publications.

Gignac, Francis. 1981. A grammar of the Greek papyri of the Roman and Byzantine periods, vol. 2: Morphology. Milano: Cisalpino-La Goliardica.

Giorgi, Alessandra \& Fabio Pianesi. 1997. Tense and aspect: From semantics to morphosyntax. Oxford \& NY: Oxford University Press.

Grosu, Alexander. 1994. Three studies in locality and case. London: Routledge.

Grosu, Alexander \& Fred Landman. 1998. Strange relatives of the third kind. Natural Language Semantics 6. 125-170.

Heim, Irene. 1987. Where does the definiteness restriction apply? Evidence from the definiteness of variables. In Eric Reuland \& Alice ter Meulen (eds.), The representation of (in)definiteness, 21-42. Cambridge, MA: MIT Press.

Hiraiwa, Ken. 2017. Internally headed relative clauses. In Martin Everaert \& Henk van Riemsdijk (eds.), The Wiley Blackwell companion to syntax (second edition), Oxford, UK: Wiley-Blackwell. doi:10.1002/9781118358733.wbsyncom028.

Holton, David, Geoffrey Horrocks, Marjolijne Janssen, Stamatina Lentari, Io Manolessou \& Notis Toufexis. 2019. The Cambridge grammar of Medieval and Early Modern Greek, vols. 2, 4). Cambridge, UK: Cambridge University Press.

Holton, David, Peter Mackridge \& Irene Philippaki-Warburton. 2012[1997]. Greek: A comprehensive grammar of the modern language (revised by Vasilis Spryopoulos). London \& NY: Routledge.

Horrocks, Geoffrey. 2010[1997]. Greek: A history of the language and its speakers. Oxford, UK: Wiley-Blackwell.

Hulsey, Sarah \& Uli Sauerland. 2006. Sorting out relative clauses. Natural Language Semantics 14. 111-137.

Jannaris, Antonius. 1987[1897]. An historical Greek grammar. London: Macmillan \& Co.

Janse, Mark. 1998a. Grammaticalization and typological change: The clitic cline in Asia Minor Greek. In Mark Janse (ed.), Productivity and creativity: Studies in general and descriptive linguistics in honor of E.M. Uhlenbeck, 521-547. Berlin: Mouton de Gruyter.

Janse, Mark. 1998b. Le grec au contact du turc: Le cas des relatives en cappadocien. In Bernard Caron (ed.), Proceedings of the 16th International Congress of Linguistics, 20-25 July 1997, Paper No. 393. Oxford: Pergamon Press.

Janse, Mark. 1999. Greek, Turkish, and Cappadocian relatives revis(it)ed. In Georgios Babiniotis (ed.), Greek linguistics 97: Proceedings of the 3rd International Conference on Greek Linguistics, 463-452. Athens: Elinika Gramata.

Janse, Mark. to appear. I Kappadokiki dialektos [The Cappadocian dialect]. In Christos Tzitzilis (ed.), Neoelinikes dialekti [modern Greek dialects], Thessaloniki: Institute of Modern Greek Studies [Manolis Triandaphyllidis Foundation]. 
Joseph, Brian. 1983. The synchrony and diachrony of the Balkan infinitive: A study in areal, general and historical linguistics. Cambridge, UK: Cambridge University Press.

Kapsomenakis, Stylianos. 1938. Voruntersuchungen zu einer Grammatik der Papyri der nachristlichen Zeit. Munich: Beck.

Karatsareas, Petros. 2011. A study of Cappadocian Greek nominal morphology from a diachronic and dialectological perspective: University of Cambridge dissertation.

Karolidis, Pavlos. 1885. Glossarion sigkritikon Elinokapadokikon lekseon [Comparative glossary of Greek-Cappadocian words]. Izmir: Musion ke vivliothiki evangelikis scholis.

Kayne, Richard. 1994. The antisymmetry of syntax. Cambridge, MA: MIT Press.

Keenan, Edward \& Bernard Comrie. 1977. Noun phrase accessibility and universal grammar. Linguistic Inquiry 8. 63-99.

Kirk, Allison. 2012. Word order and information structure in New Testament Greek: Leiden University dissertation.

Kisilier, Maxim. 2009. Yazyk i kultura mariupolckix grekov 1 [language and culture of Mariupolitan Greeks 1]. St. Petersburg: Aleteia.

Kornfilt, Jaklin. 1997. Turkish. London \& NY: Routledge.

Kotzoglou, George \& Spyridoula Varlokosta. 2005. Clitics in Greek restrictive relatives: an integrated approach. Reading Working Papers in Linguistics 8. 27-49.

Kriki, Eirini. 2013. Morfosintaktiki neoterismi sti glossa ton mi filologikon papiron: I anaforikes protasis [Morphosyntactic innovations in the language of the non-philological papyri: The relative clauses]: Aristotle University of Thessaloniki dissertation.

de Lagarde, Paul. 1886. NeuGriechisches aus Klein Asien. Göttingen: Eieterichsche VerlagsBuchhandlung.

Lees, Robert. 1961. The constituent structure of noun phrases. American Speech 36. 159-168.

Lekakou, Marika \& Petros Karatsareas. 2016. Marking definiteness multiply: Evidence from two varieties of Greek. Studies in Greek Linguistics 36. 189-203.

Levidis, Anastasios. 1892. Pragmatia peri tis en Kappadokia lalumenis glosis [A treatise on the language spoken in Cappadocia]. Ms., Center of Asia Minor Studies.

Liosis, Nikos \& Eirini Kriki. 2013. Towards a typology of relative clauses in Modern Greek dialects. In Mark Janse, Brian Joseph, Angela Ralli \& Metin Bagriacik (eds.), Online proceedings of the 5th International Conference on Modern Greek Dialects and Linguistic Theory, 245-271. Patras: University of Patras. http://www.lmgd.philology.upatras.gr/files/MGDLT5_proceedings.pdf.

Liosis, Nikos \& Eirini Kriki. 2014. Towards a typology of relative clauses in late Medieval Greek. In George Kotzoglou (ed.), Proceedings of the 11th international conference on Greek linguistics, 895-908. Rhodes: University of Rhodes.

Loukopoulos, Dimitris \& Dimitris Loukatos. 1951. Parimies ton Farason [Idioms of Pharasa]. Athens: Center of Asia Minor Studies.

Manolessou, Io. 2004. I anaforikes protasis tis Elinikis: Diachroniki prosengisi [Relative clauses in Greek: A diachronic perspective]. In Georgis Catsimali et al. (eds.), Online proceedings of the 6th International Conference on Greek Linguistics, September 18-21, 2003, Rethymno, Rethymno: University of Crete. http://www.philology.uoc.gr/conferences/6thICGL/. 
Manolessou, Io. 2019. The historical background of the Asia Minor Greek dialects. In Angela Ralli (ed.), The morphology of Asia Minor Greek, 20-65. Leiden: Brill.

Mayser, Edwin. 1934. Grammatik der griechischen Papyri aus der Ptolemäerzeit, vol. 3.2: Satzlehre. Berlin \& Leipzig: Walter de Gruyter \& Co.

Montrul, Silvina. 2016. The acquisition of heritage languages. Cambridge, UK: Cambridge University Press.

Nicholas, Nick. 1998a. To $\alpha \pi \varepsilon \rho$ and о олоьо : Untangling Mediaeval Greek relativization. In Brian Joseph, Geoffrey Horrocks \& Irene Philippaki-Warburton (eds.), Themes in Greek linguistics 2, 283-323. Amsterdam \& Philadelphia: John Benjamins.

Nicholas, Nick. 1998b. The story of pu: The grammaticalisation in space and time of a Modern Greek complementizer: University of Melbourne dissertation.

Oeconomides, Demosthenes E. 1958. Gramatiki tis elinikis dialektu tu Pontu [Grammar of the Greek dialect of Pontus]. Athens: Academy of Athens.

Papadopoulos, Iordanis V. 2006. I ekpedevsi sti Kapadokia apo tis arhes tu 19u eona os tin antalagi ton plithismon [Education in Cappadocia from the beginning of the 19th century until the population exchange]. In O elinismos tis Mikras Asias apo tin arheotita mehri ti Megali Eksodo [Hellenism in Asia Minor from antiquity till the Greek exodus], 155-186. Athens: KE.MI.PO.

Papadopoulos, Iordanis V. 2011. Kapadokika paramithia ke laikes paradosis: Farasa, Sili, Aravan, Ghurdhuno [Cappadocian stories and lore: Pharasa, Silli, Aravan and Ghourzono]. Athens: KE.MI.PO.

Partee, Barbara. 1975. Montague grammar and transformational grammar. Linguistic Inquiry 6. 203300.

Polinsky, Maria. 2018. Heritage languages and their speakers. Cambridge, UK: Cambridge University Press.

Probert, Philomen. 2015. Early Greek relative clauses. Oxford \& NY: Oxford University Press.

Revithiadou, Anthi \& Vassilios Spyropoulos. 2012. Ofitiki: Ptiches tis grammatikis domis mias Pontiakis dialektou [Ophitic: Aspects of the grammatical structure of a Pontic dialect]. Thessaloniki: Kyriakidis.

Rijksbaron, Albert. 1986. Relative clause formation in Ancient Greek. In Machtelt Bolkestein, Henk Combé, Casper De Groot, Jadranka Gvozdanović, Albert Rijksbaron \& Co Vet (eds.), Predication and expression in Functional Grammar, 235-259. London \& NY: Academic Press.

Rizzi, Luigi. 1990. Relativized minimality. Cambridge, MA: MIT Press.

Rizzi, Luigi. 1997. The fine structure of the left periphery. In Liliane Haegeman (ed.), Elements of grammar, 281-337. Dordrecht: Kluwer.

Roussou, Anna. 2000. On the left periphery: Modal particles and complementisers. Journal of Greek Linguistics 1. 65-94.

Sarantidis, Archelaos I. 1899. I Sinasos [Sinasos]. Athens: Tipografeion Ioannou Nikolaïdou.

Sauerland, Uli. 1998. The meaning of chains. Cambridge, MA: MIT dissertation.

Sauerland, Uli. 2000. Two structures for English restrictive relative clauses. In Mamoru Saito (ed.), Proceedings of the Nanzan GLOW, 351-366. Nagoya: Nanzan University Press. 
Schachter, Paul. 1973. Focus and relativization. Language 49. 19-46.

Schroeder, Christoph. 2002. On the structure of spoken Turkish. ELIS-e: Essener Linguistische Skripte - elektronisch 2. 73-90.

Sichel, Ivy. 2014. Resumptive pronouns and competition. Linguistic Inquiry 45. 655-693.

Sitaridou, Ioanna. 2013. Greek-speaking enclaves in Pontus today: the documentation and revitalization of Romeyka. In Mari C. Jones \& Sarah Ogilvie (eds.), Keeping languages alive. Language endangerment: Documentation, pedagogy and revitalization, 98-112. Cambridge, UK: Cambridge University Press.

Sitaridou, Ioanna. 2014. The Romeyka infinitive continuity, contact and change in the Hellenic varieties of Pontus. Diachronica 31. 23-73.

Symeonidis, Charalampos \& Dimitrios Tompaidis. 1999. I simerini elliniki dialektos tis Ukranias [the contemporary Greek dialect of Ukraine]. Athens: Epitropi Pontiakon Meleton.

Theodoridis, Theodoros. 1950s. Viografiko [Autobiography]. Unpublished Manuscript deposited at the Center of Asia Minor Studies.

Thomason, Sarah. 2001. Language contact: An introduction. Edinburgh: Edinburg University Press.

Triandaphyllidis, Periklis. 1993[1938]. Neoeliniki grammatiki, tom. A': Istoriki isagogi [Modern Greek grammar, vol. 1: A historical introduction. Thessaloniki: INES.

Trinchera, Francisco (ed.). 1865. Syllabus graecarum membranarum. Naples: Cataneo.

Vergnaud, Jean. 1974. French relative clauses: MIT dissertation.

de Vries, Mark. 2002. The syntax of relativization: University of Amsterdam dissertation.

de Vries, Mark. 2006. The syntax of appositive relativization: on specifying coordination, false free relatives, and promotion. Linguistic Inquiry 37. 229-270. 